\title{
Beyond the Shadow of William Briggs Part II: Canadian-Authored Titles and the Commitment to Canadian Writing
}

\author{
Janet B. Friskney ${ }^{\dagger}$
}

After William Briggs's accession to the office of Book Steward of the Methodist Book and Publishing House in June I 879, book publishing became more prominent among the House's activities and its commitment to Canadian writing more explicit. W. Stewart Wallace's checklist, The Ryerson Imprint, records an annual average output of eighteen books or pamphlets for the first thirty years of Briggs's tenure - an average six times that of the previous fifty years. Since Wallace limited the titles he listed for this period noting only works by Canadian writers - and also overlooked some Canadian-authored titles which are recorded in the trade papers, the Christian Guardian, or the House's sales books, it is apparent that book publishing was an even more substantial activity than the checklist discloses. While the House did publish Canadian editions or issues of many foreign-authored titles, the discussion here will concern itself solely with books or pamphlets by Canadian authors.

Surviving documentation related to the House's publication of books by Canadian writers between 1879 and I9I9 is revealing of the institution's place within continuums of both Methodist publishing and Canadian publishing. It also establishes the influence of individuals at work within the House upon those endeavours. As one of Briggs's contemporaries expressed it, the Book Steward was not a 'literary critic' ${ }_{i}{ }^{\mathrm{I}}$ he respected the opinions of others in literary matters and would act on their recommendations. Thus, a richer understanding results when one ranges beyond the long-held perspective that Briggs was the predominant force behind the House's publication of Canadian-authored titles.

During the Briggs period a conceptual shift took place which allowed the existing concern for the development of a Canadian

† Janet Friskney is a doctoral student in history at Carleton University. Part I ('Setting the Stage and Introducing the Players') of 'Beyond the Shadow of William Briggs' was published in the Papers/Cahiers 33, no. 2 (Fall I995): I 2 I-63. 
Methodist literature to be transmuted into a broader commitment to Canadian writing. However, it is unlikely it would have been acted upon to any great degree had improved conditions for book publishing in Canada and the House's own growth and diversity as a business not been there to support it. Moreover, as will become clear, the publication of Canadian-authored books was pursued within the boundaries of acceptable risk; while the House certainly deserves acknowledgment for its support of Canadian writing during this period, it was never financially reckless in its pursuit of that interest.

Briggs's inaugural address in the Christian Guardian in July I 879 expressed no specific commitment to developing the House's book publishing sector. However, he did make clear an interest in publishing books at the Book Committee meeting immediately following his appointment. On that occasion he suggested publishing a religious work by Reverend W.H. Poole and an illustrated history of Methodism. The committee rejected both proposals, deeming them inexpedient. ${ }^{2}$ It did provisionally agree, however, to publish George H. Cornish's Cyclopaedia of Methodism in Canada:

[T]his Committee having heard the statement of Bro. G.H. Cornish respecting his proposed Encyclopedia believes that such a work would meet a felt necessity but at the same time we feel it would be a considerable risk unless by subscription or otherwise the publisher be secured against loss. It is therefore recommended that a prospectus be prepared and published in the Guardian and in circular form describing the nature of the work ... and that as soon as a sufficient number of subscribers is secured to cover the cost of publication, that the work be published by the Book Room. ${ }^{3}$

A prospectus duly appeared in the Christian Guardian, stating that the 'author has determined not to publish until a sufficient number of copies is subscribed for to cover the cost of publication.' ${ }^{4}$ Cornish's book, which emerged from the press in I88I, was an 850-page monument to Canadian Methodism, containing historical, educational, and statistical information about the church to 1880. Despite the prospectus's warning that publication would not be undertaken until costs were covered by subscriptions, this appears not to have happened. In May I 883 Cornish appeared before the Book Committee to plead his case:

The Rev. Geo. Cornish was introduced and made a statement respecting his Cyclopaedia. A sufficient number had not been sold 
to pay expense of publication. He requested that the Book Steward should take the unsold copies, or in some way relieve him from the pressure occasioned by the publication. No action was taken. ${ }^{5}$

Ironically, the General Conference of 1878 had requested that Cornish undertake the project in the first place. Moreover, the first few pages of the book include excerpts from the minutes of the General, London, and Toronto Conferences in which the members pledged their support for Cornish's work. Obviously such 'support' did not mean that the cost of publication would be absorbed by the church nor that the ministers would be more than morally obligated to purchase a copy. No further mention of Cornish's plight appears in the Book Committee minutes. However, a second volume, also published by subscription, appeared in 1902. In March of that year Briggs promoted the book in the Christian Guardian, encouraging further subscriptions and revealing that the author had determined that he could not 'undertake the financial responsibility therein, unless he can secure at least four hundred more subscribers. ${ }^{6}$ After his experiences with both the Hand-Book of Canadian Methodism (I 867), for which many ministers who had subscribed for copies had refused to pay, ${ }^{7}$ and the first volume of his encyclopedia, Cornish had learned the value of caution.

With the exception of concerns surrounding the publication of hymn books, the Book Committee minutes record little about the House's book publishing activities during the remainder of Briggs's tenure. Never having made it one of its focal points in the past, the Book Committee, apparently, was content to leave book publishing to the discretion of the Book Steward. While the Conference Minutes of 1837 , which had set out the regulations for the church's book and printing establishment, stated that the Book Committee was to pass judgment on manuscripts submitted to the House for publication, ${ }^{8}$ in practice book publishing enjoyed no official status with the church. That is, the church had not created a book editor position nor specifically appointed a minister to serve in such a capacity. Given this circumstance, it is not surprising that the matter generated so little attention at Book Committee meetings. Book publishing initiatives undertaken during Briggs's tenure were primarily carried out by those within the House rather than those within the larger church body.

Throughout the first decade of Briggs's stewardship religious publications continued to dominate the House's book publishing. Indeed, the publication of a new hymn book spurred the House's 
I 880 renovations. 9 At the General Conference in 1882 the Book Committee reported:

The most noteworthy feature in connection with our Book Room and Publishing interests during the Quadrennium, has been the successive issue of six editions of the New Hymn-book, varying in size and price from the small pearl type edition to the large Pulpit Hymn-book. Of these, there have been printed and bound up to date, I 50,000 copies. ${ }^{\text {IO }}$

Sermons continued to appear as did works which added to the body of Canadian Methodist literature. The latter included Alexander Burns and Edward Bradshaw Ryckman's The Obligations of Theology to Science, and The Divine Call to the Ministry (I88I), an edition of Wesley's Doctrinal Standards (I 88 I) edited by prominent Canadian Methodist Nathaniel Burwash (including an introduction, analysis, and notes), Alexander Sutherland's A Summer in Prairie Land (I88I), and John Carroll's My Boy Life (r882). Carroll's autobiographical work originally appeared in one of the House's Sunday school papers.

W.H. Withrow, in turn, extended the House's contributions to Canadian Methodist literature with a number of historical romances. In 1879 his first fictional work, The King's Messenger; or, Lawrence Temple's Probation: A Story of Canadian Life, emerged from the press. The work had initially appeared serially in the Canadian Methodist Magazine in 1878 , written when he had been unable to find a suitable story for the periodical. ${ }^{\text {II }}$ The following year the House published two further fictional works by Withrow: Neville Trueman, the Pioneer Preacher: A Tale of the War of $I 8 I 2$ and Valeria, the Martyr of the Catacombs. His efforts came at the beginning of a forty-year period in which evangelical fiction was a prominent genre in Canadian literature. ${ }^{12}$ That same year Withrow also published Great Preachers, Ancient and Modern and $A$ Canadian in Europe. The latter work was a travel book which bore the dual imprint of William Briggs and Rose-Belford. ${ }^{13}$ Unfortunately, no records detailing the terms of the arrangement survive though costs and profits may have been shared. George Maclean Rose, the Rose of Rose-Belford, was lauded by one of his contemporaries as a man 'prominently associated with the development of Canadian literature' and, thus, may have been willing to risk some money on a writer who was held in as much esteem as Withrow. ${ }^{\mathrm{I}}$

Works by William Kirby also emerged from the House early in Briggs's term. In I 879 Kirby's The Hungry Year (I 5 pp.) appeared 
followed by Canadian Idylls, Number IV: Spring, Stoney Creek in I880. The latter work was first printed in the Canadian Methodist Magazine. Upon initially reading it, Withrow wrote enthusiastically to Kirby: 'I cannot tell you with what pleasure I read your beautiful poem. I think it is the best of the series. I shall be happy to use it in two parts [in the magazine] and send to you 50 copies of the whole in pamphlet form. ${ }^{\prime 5} \mathrm{He}$ also said that he would ask Briggs to take on the risk of publishing this poem, along with its three companion pieces. Briggs, however, was unwilling to do so. Withrow explained to Kirby six weeks later: '[Mr. Briggs] is only recently appointed manager $\&$ has adopted the role for the present to publish on his own account only our own periodicals. ${ }^{16}$ His words imply that Briggs entered into the management of the House with no definite plans for pursuing original book publishing. Nevertheless, the Book Steward was interested enough in Kirby's work to make the following suggestion:

[Mr. Briggs] makes this offer. He will charge nothing for the composition of the last poem - Stony Creek, which will be in type for the Magazine - but will overrun it for a . . book to be neatly bound in cloth with worked design. He will charge for the composition of the other three poems[,] for paper[,] prepwork \& binding for 500 copies, $\$ 100$. The binding costs exactly half that sum.... Mr. Briggs says our House here and at Montreal would do its best to sell the book. I think a considerable no. w[oul]d be sold at our Conferences. We would put it in different colour cloths. He would want $\$ 50-$ to pay wages of men - when book is published \& $\$ 50$ in 4 months. ${ }^{17}$

While Kirby did not take up Briggs's proposal - in the end, only the fourth of these verses appeared in 1880 - the offer, in most of the conditions it outlined (charges for prepwork, binding, paper, etc.), anticipated the basic contract Briggs would enter into with many authors during the 1890 and early 1900 .

By 1882 the House had a subscription book publishing department in place. ${ }^{18}$ John C. Berkinshaw (b.I 850), who had joined the House in I 869, managed it. Presumably it was initiated in response to the prevailing book market. While subscription book publishing had always been a part of the Canadian book trade, the practice enjoyed a particular vogue throughout North America during the 1870 s and I 880 os. ${ }^{19}$ More costly, these books 'were printed on heavy paper, had fancy bindings, [and] contained lots of illustrations'; their contents 'ranged from fiction and biography to medicine and travel books. ${ }^{20}$ 
By distributing through agents or by mail rather than through booksellers, subscription publishers could save on overhead costs. ${ }^{2 I}$ Agents would carry prospectuses of available and forthcoming titles as well as samples of binding, type, and illustrations. ${ }^{22}$ Most major Canadian publishers of the period, including John Lovell, Hunter, Rose, and Thomas Maclear, were engaged in subscription book publishing. ${ }^{23}$ The Belden Brothers's well known series of county atlases was sold in this manner. The Methodist Book and Publishing House's subscription book publishing department co-existed alongside its book publishing department through the 1890 ond at least through the first decade of the twentieth century. ${ }^{24}$

Egerton Ryerson's two volume, The Loyalists of America and their Times from 1620 to I 816 (I 880), may have been a subscription publication. Certainly, Briggs advertised for agents to sell the work; moreover, at $\$ 5.00$ in English cloth or \$7.00 in half morocco it was expensive. ${ }^{25}$ It bore a multiple imprint of three Toronto publishers - William Briggs, James Campbell and Son, and Willing and Williamson - as well as that of Dawson Brothers of Montreal; positive reviews appeared in newspapers from Toronto, Hamilton, Montreal, and Halifax, and the House printed two large editions the year of its issue. ${ }^{26}$ Carl Berger has argued that it 'became one of the major literary sources of the [United Empire Loyalist] tradition. ${ }^{27}$ As he explains, the Loyalist

\footnotetext{
tradition expressed an indigenous British-Canadian national feeling and it flourished both because it provided a useful device by which the arguments of the advocates of Canadian independence could be counteracted, and because it bolstered the status of loyalist descendants by associating their ancestors with the foundation of national greatness. ${ }^{28}$
}

Given Ryerson's own Loyalist heritage and his connection to Methodism, it is not surprising that he undertook the work. Ontario Methodism identified itself with the Loyalist tradition since many of its earliest members had come to Upper Canada as a result of the American Revolution. Pertinently, however, the House advertised The Loyalists of America as a work of 'national importance' rather than one of importance to Methodism and emphasized that the 'grand patriotism of our country, struggling against tremendous odds, is amply asserted and illustrated. ${ }^{29}$ Thus, one finds an interest in Canadian history as well as an ambition to reach beyond the Methodist community being demonstrated by the House in 1880 . 
Two further works by Ryerson, Canadian Methodism: Its Epochs and Characteristics (1882) and The Story of My Life (I883), appeared soon after his Loyalist history. The former, derived from a series of articles initially written for the Canadian Methodist Magazine, was produced at the request of the Toronto, Montreal, and London Conferences. The latter appeared the year following Ryerson's death; although its title suggests that it is the author's autobiography, the actual book was compiled by J. George Hodgins, Ryerson's literary executor, from the documents left to him by Ryerson. ${ }^{30}$

Scattered among the sermons and religious discourses the House released in the mid-I880s are a number of titles reflective of the Methodist Church's concerns at that time. These include B.F. Austin's The Gospel to the Poor Versus Pew Rents (1884), E.H. Dewart's University Federation, Considered in its Relation to the Educational Interests of the Methodist Church (I886), and works on temperance. These years also saw such publications as David Hickey's William and Mary: A Tale of the Siege of Louisburg (1 884), William Kirby's 2o-page The United Empire Loyalists of Canada (I884), which was reprinted from the Canadian Methodist Magazine, and Conygham Crawford Taylor's Toronto 'Called Back', from I 886 to I 850: Its Wonderful Growth and Progress (I 886). The latter work went through a number of editions under various titles. ${ }^{3 \mathrm{I}}$ Yet the book was printed at the expense of the author, and when Taylor died in 1898 he still owed the House over \$200.00; Briggs opted to take over the remaining stock from Taylor's widow and children in lieu of payment. ${ }^{32}$

The House's pursuit of book publishing may well have been encouraged by the 1884 Methodist union. As the union substantially increased the circulation of the Christian Guardian and the periodicals, it is reasonable to suppose it also improved the sales of the House's books. Indeed, the increased circulation of those papers meant that more people were being exposed to the House's book advertisements. By I 886 the House's book publishing activity was substantial enough to merit a sub-section of its own in the Book Committee's Report to the General Conference:

This Department of the business is one of very great value and importance. The profit on books published by ourselves is larger, and we have control of them in the market. Thus also an opportunity is afforded for developing the literary ability existing in the Church, whereby many works may be expected distinctively Canadian in their conception, and therefore successful in a high degree 
in their appeal to the Canadian mind. An additional advantage is that, as the House continues to publish, we can in increasing proportion vouch for the works supplied through our agencies. ${ }^{33}$

The report reiterated the importance of encouraging Canadian Methodist authorship. However, the connection it drew between writers and readers had a Canadian rather than a Methodist focus. Implicitly, if not explicitly, it favoured the publication of books that would appeal to a broader Canadian audience. Given the church's prevailing national focus and the literary nationalism of the House's two official editors, W.H. Withrow and E.H. Dewart, such a perspective would not have been out of character. The report's final assertion - that the House could vouch for its own publications more readily than those of other establishments - was consistent with the establishment's moral imperative to provide a wholesome alternative to the kinds of less worthy publications which were then readily available.

The House's activities were not out of character with those of other Canadian operations. By the 1880 s a number of booksellers and printers were issuing Canadian-authored titles, including Toronto's Grip Printing and Publishing Company and Hunter, Rose. The latter's list included reference works, social histories, and, to a smaller degree, imaginative literature. William Drysdale of Montreal provides a closer parallel to the House; he produced a mixture of religious and secular works, issuing temperance and Presbyterian books as well as historical and imaginative literature. ${ }^{34}$ In I 889 Drysdale released W.D. Lighthall's important anthology, Songs of the Great Dominion, 'which first introduced the "Confederation Poets" to an international audience.'35

In 1887 the House published three volumes of verse: Robert Awde's Jubilee, Patriotic and Other Poems, Thomas James MacMurray's The Legend of Delaware Valley, and Other Poems, and Thomas O'Hagan's A Gate of Flowers, and Other Poems. O'Hagan was notable enough to merit a study in the Canadian Magazine in $1893 .{ }^{36}$ From a literary perspective, the most important book appearing that year was An Abridged History of Canada . . Also, An Outline History of Canadian Literature. Co-authored by W.H. Withrow and G. Mercer Adam, the former writing the general history and the latter the literary, this book marked the House's first excursion into Canadian literary criticism in book form. The authors received a $\$ 50.00$ royalty on an edition of 1,000 copies; a second edition of 500 copies appeared in 1889.37 Adam was a 
prominent member of the Canadian literary community (he had been involved, for example, with both the British American Magazine and the Canadian Monthly and National Review) who 'promoted a literary life for Canada. ${ }^{38}$ Like so many of his contemporaries, including Withrow and Dewart, he saw a national literature as integral to Canada's nationhood:

What is wanted to help our own nascent literature is a greater infusion into it of patriotic feeling, and, among the people, a wider diffusion of national sentiment. Through no influence more potent than literature and the literary spirit can the nationalizing of the Dominion effectively operate. Nothing will better contribute to the welding process, or be more efficient in bringing about homogeneity, and the consolidating influences the country so urgently needs, than a healthy native literature and an ardent national sentiment. 39

Adam's survey discussed works written by both Francophones and Anglophones and included categories addressing the efforts of explorers, traders, and early colonists, as well as Loyalist, descriptive, and social literature. His attention was clearly directed to Canadian literature as a whole rather than Canadian Methodist literature. The House's publication of Adam's work demonstrated its own strengthening interest in the broader field of Canadian letters.

Between I 888 and I 892 the House published an eclectic collection of books. Sermons, religious works, poetry, fiction, history, and education texts all appeared. An interest in Canada is evidenced by Withrow's Our Own Country: Canada, Scenic and Descriptive (1889), Lady Matilda Edgar's Ten Years of Upper Canada in Peace and War (1 890), and Robert B. Hill's Manitoba: History of its Early Settlement, Development and Resources (I 890). In I 890 the House also issued a Canadian edition of Egerton Ryerson Young's By Canoe and Dog Train Among the Cree and Salteaux Indians. Young, who was a Methodist minister, used his travel and mission experience among northern Natives as a source for his narrative. The work had a popular sale in Canada, England, and the United States, and in I 893 the House issued a second Canadian edition. Noting this success, Books and Notions remarked: 'The Canadian people are beginning to appreciate the work of their own book makers.' 40

The year I 893 was a watershed in the history of the House's book publishing. That year for the first time secular works dominated its list. Among the books issued were a biography and an auto- 
biography, a school text, a work on Cape Breton, and three volumes of verse. The poetry included Sir James Edgar's This Canada of Ours, and Other Poems, Charles G.D. Roberts's Songs of the Common Day, and William Wilfred Campbell's The Dread Voyage. Also published was Egerton Ryerson Young's Stories from Indian Wigwams and Northern Camp-Fires. Twice that year Books and Notions praised the House's commitment to Canadian literature. Noting in April the forthcoming publication of The Dread Voyage, it reported:

The Methodist Book and Publishing House are to be congratulated on this addition to their already large list of Canadian publications. They have done a great deal for Canadian books, and their lists of books by Canadian authors should be in the hands of every bookseller. Everybody knows, and no one better than the bookseller, that Canadian literature has hitherto brought no profit to either publisher or author, and when a publishing firm will, in spite of such general experience, lay itself to the task of popularizing Canadian books and authors, they deserve all the assistance which can consistently be given them. They publish works by nearly all the leading Canadian authors, and are rapidly adding to the list. They also publish books concerning Canada which are worthy of being on every bookseller's counter. Any book which bears their imprint can be taken with assurance to be reliable in every way and worthy of any reader's attention..$^{4}$

The explicit commitment to publishing Canadian-authored titles that so clearly manifested itself in I 893 should be accredited to a conjunction of circumstances rather than a single cause. By the early 1890 os the Methodist Book and Publishing House had emerged as the largest printing and publishing establishment in Canada. ${ }^{42}$ The House could afford to pursue an interest in Canadian writing because of the returns generated from other areas of the business and the opportunities provided by changing conditions of the Canadian book trade. The 189I Anglo-American Copyright Agreement, which brought to a close the era of piracy between Britain and the United States and between Canada and the United States, also initiated a shift to agency publishing and encouraged British and American publishers 'to make legal arrangements and joint ventures with Canadian publishers, for issuing books by Canadian and non-Canadian writers. ${ }^{43}$ Roberts's, Campbell's and Young's works, for example, were all co-publications with foreign houses. In fact, 
publication of Campbell's volume was delayed because of difficulties in getting an American publisher. ${ }^{44}$ Moreover, as Canadian authors of international appeal started to appear, British and American publishers began to look at Canadian writers with more interest.

The prevailing attitudes of the Methodist Church also created a more receptive environment for the encouragement of Canadian authorship. The I 884 union had encouraged the church's existing Canadian consciousness and promoted a national perspective. Members of the church community had already expressed concern about developing a Canadian Methodist literature. These two circumstances in combination may have sparked the ambition to produce and to promote Canadian writing in general. Moreover, secular book publishing only began to dominate the House's list in the 1890 , a decade in which the social gospel was taking hold. The movement's bid to extend the church's reach from the sacred into the secular world would not have prohibited an interest in the nation's literature. Indeed, given the prevailing view that a country's literary output 'was by definition the expression of a nation, ${ }^{\prime 45}$ Canada's literature may well have existed as one method of measuring the social gospel's achievements.

Finally, the secularization taking place within the business as a whole during the 1890 s made an impact. By 1892 E.S. Caswell and S.B. Gundy, two non-clerical employees (though both sons of Methodist ministers), were in place as managers of the book publishing and wholesale departments respectively. Each wielded influence with Briggs, and each passed judgment on the potential or importance of specific works. Along with their successors, they would influence the House's book publishing endeavours and its commitment to Canadian writing over the next three decades.

The Book Committee report to the General Conference in 1894 remarked on the growth of the House's book publishing activities, stating its belief that the establishment's excellent printing and binding facilities drew a good portion of the country's book publishing business. Moreover, it asserted that the House was now acknowledged as a book publishing concern and that the 'number and importance of our book publications have given us a standing second to none in Canada in this line of business enterprise.'46 Contemporary comments uphold this statement. Writing to a literary acquaintance in 1893 , Bliss Carman recommended William Briggs as a Canadian publisher, remarking: 'I don't know him personally, but Roberts tells me he is the most enterprising and reliable publisher in Canada. ${ }^{47}$ Though not completely impressed 
with Briggs as a publisher, Archibald Lampman, for his part, wrote E.W. Thomson in March I896: 'We really have no publisher in the country except Briggs. ${ }^{48}$ Duncan Campbell Scott expressed similar sentiments in a letter to his American publisher, Copeland and Day, that same month:

Canadian publishers are notoriously cautious and it is almost impossible to make any arrangements with them but I think it would be well to try. William Briggs of Toronto, or The Copp Clarke Co. [sic] of the same place are the only publishers I would advise approaching. ... The former operates the Methodist Book Concern and is the largest publisher in Canada. You had better try him first. Copp Clarke Co publish educational books largely and I do not think they would care about handling the book. Briggs is the best man to put the book on our market and I think he should readily consent to do that even if he refuses to take an edition. 49

Though Scott had doubts about Copp, Clark in 1896 , both that firm and George Morang were demonstrating a clear commitment to Canadian authorship by the late r89os. Like the House, these companies 'had a solid base in text-books, and combined this with their extensive wholesale operations to move into agency and original publishing. ${ }^{50}$ William Copp issued Canadian writers such as Henry Scadding, John George Bourinot, and Gilbert Parker. George Morang, who would establish his company in 1899 , published work by Pauline Johnson, Archibald Lampman, Susan Frances Harrison, Jean Blewett, and Ernest Thompson Seton. Morang's most ambitious venture, The Makers of Canada Series, appeared between I903 and I9I I under the general editorship of Victoria College professor Pelham Edgar and the poet Duncan Campbell Scott. In I905 the Canadian Magazine collectively praised Morang, Copp, and Briggs for their efforts on behalf of Canadian literature. ${ }^{5 \mathrm{I}}$

In considering the House's publication of Canadian-authored titles during the I 890 s and early I900s, it must be understood that a good portion of these books were not produced at the House's expense. Quite a number of contracts between William Briggs and writers or publishers survive for the years after $1890 . .^{52}$ Excepting Briggs's contracts with other publishers, approximately seventy per cent of the existing book contracts are printing agreements. For the most part, these contracts committed the House to producing an edition of 500 to $\mathrm{I}, 500$ copies of a book for the author and generally included a clause stating that the House would market the book for 
a commission. That commission was usually forty or fifty per cent. The contracts for books the House did take on at its own risk ordinarily offered the author a ten per cent royalty on the retail price based on an edition of 500 or I,000 copies. Both the House's practice of printing primarily at the author's expense and the size of the editions it published were consistent with the Canadian book trade of the period.

The business correspondence of the Methodist Book and Publishing House to William Canniff and Catharine Parr Traill offers insight into the House's book publishing practices during the I $890 \mathrm{os}$. Canniff published his history, The Medical Profession in Upper Canada, 1783-1850: An Historical Narrative, with Original Documents Relating to the Profession, including Some Brief Biographies (668 pp.), through the House's subscription book department in I894. The related correspondence reveals the author's intimate involvement in his book's sales and marketing.

Canniff submitted a list of subscribers to the House prior to publication. While the House looked after distributing the work to those subscribers, problems encountered over delivery and collection of payment were referred back to Canniff. J.C. Berkinshaw's I 8 June 1894 letter to the author offers a litany of troubles in this regard: one subscriber challenged the price of the work, stating he had been 'promised the book at \$3.00' rather than \$3.50; a second said his financial circumstances had changed since he had subscribed and he could no longer purchase the work; a third held that he had never signed for it and though he could not say the signature on the list did 'not look unlike' his wife's, 'on enquiry' his wife stated that she did 'not remember ever signing for it'; a fourth, who had agreed to purchase two copies, said that one had been ordered as a gift but, in the interim, the intended recipient had died and thus, that copy was no longer required. Indeed, Berkinshaw continued, this particular subscriber had 'stated that he [now] did not care for any, but we presume that one of the copies was for himself, and will try and place it. Is this right?' 53 Berkinshaw further reported they had been unable to find two subscribers and that he had received an enquiry about selling the work 'to the trade at a discount.' However, he discouraged the latter strategy: 'So far we have not done so, thinking that you would prefer to get subscribers for the balance of the edition rather than to allow it to be sold through book-sellers. We think that you had better secure the subscribers, and know exactly where every copy is placed.' 54 As subscription sales yielded higher profits, Berkinshaw's recommendation was not surprising. 
His reference to 'the balance of the edition' also reveals that the whole edition had not been subscribed for prior to publication. As payments for the book came in, they were credited directly to Canniff's account - presumably to offset actual production costs. ${ }^{55}$ Subsequent letters provide further instances of Canniff's involvement. When individuals enquired at the House about canvassing for the work, Canniff was asked whether he would like to accept these offers and, if so, on what terms. ${ }^{56}$ Canniff also opted to have circulars made up against the advice of Berkinshaw, who believed 'it would be very little use and only add extra expense unless you have a good list of names that would be interested in the book, and likely to purchase. ${ }^{57}$ However, in the face of poor sales, Berkinshaw warmed to this idea by April I 895:

We have tried several men with your book, and each and all returned the pros[pectus]. We don't know, any better way at present than making up a list and trying to secure orders by circular and reply card. We think that if you can make up such a list it will be to the advantage of both parties interested. ${ }^{58}$

Berkinshaw's reference to 'both parties interested' suggests that the original subscriptions had not covered the book's full production costs. If so, Canniff's position would have echoed that of George Cornish's in the early 188 os. The Canadian medical community, it appears, was as apathetic in its response to The Medical Profession in Upper Canada as Canadian Methodists had been to the Cyclopaedia of Methodism in Canada.

Though it is important to recognize Canniff's involvement in his book's sale and marketing, one must also acknowledge the House's endeavours on the author's behalf. The House did not merely manufacture the work; it also served as a liaison for the author, taking inquiries from potential canvassers, distributing the book, offering advice about marketing, and also sending out review copies to newspapers and journals. Included among the latter were the Globe, the Mail and Empire, the Week, the Canadian Magazine, the Hamilton Spectator, the Hamilton Times, the London Advertiser, the London Free Press, the Kingston News, the Kingston British Whig, and the Ottawa Citizen. ${ }^{59}$ The choice of Ontariobased publications may have reflected an Ontario bias in the House's general marketing practice, or, alternately, may simply have been an acknowledgment of the book's Upper Canadian focus. The House collected resulting reviews and forwarded copies to Canniff. 
Granted, while the work's production costs were not paid off, the House had a vested interest in encouraging its sale; nevertheless, in choosing to publish through its subscription book department Canniff received more than straightforward printing services.

Catharine Parr Traill's Pearls and Pebbles; or, The Notes of an Old Naturalist appeared the same year as Canniff's book but, unlike Canniff, Traill dealt with E.S. Caswell and the book publishing department. She submitted her manuscript early in May I 894. By the end of the month the House responded, saying the 'reader has reported very favorably ... as far as he has yet looked through the MS' $^{\prime}$ and that Traill would hear before long as to publication. ${ }^{60}$ The House did not, in fact, write back until 5 September. (Indeed, in the interim, Traill wrote the House, cautioning it against the inherent danger of making someone her age - she was 92 - wait so long! $\left.\right|^{6 \mathrm{I}}$ The House's reply, though its author was given as William Briggs, was actually written in E.S. Caswell's hand:

We have felt extremely reluctant to say no to the proposition to publish at our own expense. It [Pearls and Pebbles] is a work of high character, to which attaches a value in the name and personality of the author that a Publisher is disposed to regard with some envy; but there is the counting of the cost which prudence dictates \& which 'gives us pause.' Thinking it over to-day this thought presented itself. Could you or some of your family or friends obtain signatures for say 200 subscribed copies of the book? If you can do this - and it seems to us easily feasible - we would not hesitate to assume the responsibility of issuing the work on the royalty plan, giving you the usual author's royalty of $10 \%$ on the published price. $^{62}$

Despite Traill's age and reputation, Briggs and Caswell were unwilling to commit the House fully to her book's production. A subscription list continued to offer an important measure of security. Indeed, as Caswell emphasized in the same letter: 'If your friends take readily to the work [of collecting subscriptions], do not stop them at 200 copies. The more the better for both author \& publisher.' All the same, Caswell's offer did reveal progress in the contract between author and publisher. His use of the term 'royalty plan' suggests that publishing books at their own risk had an established, though certainly not dominant, place in the House's book publishing activities. D.B. Read's Life and Times of Major-General Sir Isaac Brock was issued in the same year under the same terms offered to Traill. ${ }^{63}$ 
Traill accepted the terms and received an acknowledgment of her reply in a letter dated I5 September I894:

We are glad to learn that you accept the terms proposed in our last letter, and that you are prepared to commence as early as possible on the work of acquiring the necessary number of signatures. This will not be altogether congenial work, but we feel sure you have many friends who will be only too glad to assist you, and we have not the slightest doubt that you will be able to procure the number mentioned. It is, as you will perceive, in your interests as well as our own, to work up the largest possible sales. Were the Canadian market a larger one, and a better one for Canadian books, we would not think of mentioning such terms. ${ }^{64}$

The final comment points not only to the economic problems of the small, Canadian market but also to the apathetic public response to Canadian books that was characteristic of the day. In December 1894, the House released Pearls and Pebbles, which consisted of twenty-four sketches drawn from Traill's childhood reminiscences, her diaries, and her interest in nature. The work also included a biographical sketch of Traill by her grand-niece, Mary Agnes FitzGibbon. FitzGibbon had had her biography of her father, The Veteran of I 8I 2: The Life of James FitzGibbon, printed by the House earlier that year and may well have suggested that Traill submit Pearls and Pebbles to the House.

In January I 895 Caswell reported to Traill that from 'all sides come good opinions of the book' and that he hoped to 'hear soon from our Mr. Gundy that he has arranged with some English House to publish or sell the book in England. ${ }^{\prime 65}$ The following month the Methodist Magazine (formerly the Canadian Methodist Magazine) not only reviewed the work in the journal's book section but also published an article by the Toronto Schools' Inspector, James L. Hughes, which commended the noble character of both Traill and her latest effort. ${ }^{66}$ Further review copies were submitted to a variety of Canadian and American publications, among them the Week, the Canadian Magazine, the Knox College Monthly, and the Chicago Inter-Ocean. Goldwin Smith offered his opinion in the London Illustrated News. Caswell eagerly received the reviews and pondered how he might use these and the praise of prominent persons in the book's promotion, thus illustrating some of the techniques he used to encourage sales. ${ }^{67}$ In February S.B. Gundy successfully obtained an order from an English publisher. On the I 2 th of the month Caswell wrote: 
[W]e today are in receipt of an order/secured by our Mr. Gundy) from the London House of Sampson Low, Marston \& Co. for 250 copies of 'Pearls and Pebbles.' What think you of that?

'On to Edition the second' must soon be the cry. I am glad for your sake that your book, the literary child of your old age, will thus be brought prominently before the English literary world. ${ }^{68}$

Caswell was so pleased with the success of Pearls and Pebbles that he jokingly wrote to Traill: "The Publisher is not kept awake at nights trembling over possible loss on "Pearls \& Pebbles." $\mathrm{He}$ wishes he had more like it. ${ }^{\prime 69}$ By April 18957 I7 copies had been sold. ${ }^{70}$ A second edition was printed that year.

The House, however, was not encouraging about two of Traill's other proposals. In a letter dated 9 April I895, Caswell replied negatively to Traill's query about publishing a Canadian edition of Canadian Crusoes, for which she had obtained permission from her British publisher, Nelson \& Sons:

The letter from Nelson \& Sons may yet be valuable, but I do not see that we can avail ourselves of their permission to publish Canadian Crusoes in Canada. Our Canadian Copyright Act protects the Canadian publisher against the importation of American reprints, but is no barrier to the bringing in of English editions. Nelsons have that book now at a low price and they can allow book houses in Canada forty and fifty per cent, so that a Canadian Publisher could not produce it to compete with their edition. ${ }^{7 \mathrm{I}}$

During the 1890 it was quite common for more than one edition of a book to be competing in the small Canadian market. ${ }^{72}$ Copyright anomalies allowed Canadian territory to be sold more than once and, thus, a Canadian publisher could not guarantee control in the Canadian market. Indeed, the House would have been acutely aware of this problem in I895; the previous year it had arranged with T. Fisher Unwin for exclusive Canadian rights to publish S.R. Crockett's The Raiders only to have Unwin turn around and send in a colonial edition in direct competition. ${ }^{73}$ Caswell's response to Traill's second suggestion - that the House produce a series of her juvenile books - was also discouraging. He described such an undertaking as 'a work of the future,' then added:

Are you impatient with this caution of Canadian publishers? It is, I assure you, the teaching of experience. Our people have not yet 
come to appreciate rightly the books of our own authors. The booksellers will take [Arthur Conan] Doyle \& [S.R.] Crockett ... without question, but let the name of the author be Canadian known or unknown - and they fight shy. 74

Caswell's assessment that Canadians were apathetic toward their nation's literature echoed the opinions of such writers as Archibald Lampman, Duncan Campbell Scott, William Wilfred Campbell, and Sara Jeannette Duncan..$^{75}$ Despite these discouraging responses, Traill appears to have been generally happy with the House's efforts. Responding to her letter of the previous day, William Briggs wrote on II April I 895:

It is gratifying to me as a publisher to note the satisfaction you express with regard to our business dealings. We have felt it no small honor to bring out a book by an author so well known and highly esteemed on both sides of the sea. We have bent our best energies, you may believe, to giving it the widest possible publicity, and secure for it a sale satisfactory to all concerned. The confidence that you have expressed in us, as well as the very pleasant correspondence connected with the publication of this work, have been exceedingly valued by us. ${ }^{76}$

While Pearls and Pebbles was in production, Traill submitted another manuscript, this one a collection of children's stories. The House made no immediate decision, first wanting to see how Pearls and Pebbles would do. ${ }^{77}$ In the meantime, however, Caswell passed the manuscript along to a Miss Currie, his 'kindergarten friend' (likely a kindergarten teacher), who, it appears, vetted it for its potential appeal to children. ${ }^{78}$ Such a practice seems surprisingly sophisticated for an establishment which had just begun to venture more seriously into indigenous book publishing. Whether it was a common custom among Canadian publishers of the day is unknown. Caswell would similarly consult outside readers with regard to manuscripts over the next fifteen years.

To Traill's queries about her work's fate, Caswell responded reassuringly on 9 March I895, writing of Miss Currie's favourable response and adding:

'Cot \& Cradle' stories is quiescent just yet. I have not spoken to Dr. Briggs about it. I will wait until Miss F.G. [FitzGibbon edited the book for Traill] and I have talked it out, planned our campaign, and can go to him with something definite. I haven't any doubt that he will publish it, you need have no uneasiness on that score. ${ }^{79}$ 
Caswell's terminology suggests that Briggs at times had to be convinced about the wisdom of publishing a book at the House's risk. Nevertheless, Briggs did agree. The positive reception and sales of Pearls and Pebbles had provided sufficient encouragement to take the risk. In June Caswell reported that the House would publish Cot and Cradle Stories at a ten per cent royalty on retail. He assured Traill that canvassing for subscribers was not a condition of publication as had been the case with Pearls and Pebbles but did recommend she let her friends know about the book's imminent appearance. ${ }^{80}$ She was also offered a special forty per cent discount on any copies she ordered for sale. ${ }^{8 I}$ Of the stories themselves, Caswell expressed pleasure:

I am enjoying your C. \& C. as they come to me from Miss FitzGibbon's hand. Last night I read of the wrens of Westove \& their visit south, the tribulations of Mrs. Partlett \& Mrs. Dorking; the epigramatic [sic] and admonitory utterances of Mrs. Poll Parrot and the phoebes of Minnewawa, and I was a child again in my full appreciation of them. The only draw back was the feeling of selfishness that I was having all the enjoyment myself; I could wish that everybody could read them. If the book does not have an immense sale I shall despair of selling books in Canada. ${ }^{82}$

Caswell may well have despaired. The book appeared in December I 895 in time for the Christmas market but, despite his hopes and the accolades of Lady Aberdeen, it did not sell well. ${ }^{83}$ Indeed, by April I 896 only 309 copies had been purchased. ${ }^{84}$ Traill herself was disappointed with the book's illustrations and, by August, was very concerned about its sluggish sale. ${ }^{85}$ Briggs wrote back reassuringly:

With regard to 'Cot and Cradle Stories,' which you hope will not be a loss to us, I may say that I have no fear of this, although the sale has been much slower than I should have liked. You will be pleased to know that we had a letter yesterday from Messrs Sampson Low, Marston \& Co. of London, England, asking us to send them 50 copies of this book on sale. This we have done and hope they will soon have them sold, and send us another order. ${ }^{86}$

However, sales for Cot and Cradle Stories fell off as did those for Pearls and Pebbles. ${ }^{87}$ By late $\mathrm{I} 898$ Caswell had prepared a 'booklet circular' of Traill's works, as a means to 'stimulate sales. ${ }^{88}$ The price of Pearls and Pebbles was dropped from \$I.50 to \$I.25 but he assured the author that she would continue to receive the full I $5 \mathbb{C}$ royalty on any copies sold. Caswell also pondered the expediency 
of producing a cheap, paper cover edition of Cot and Cradle Stories to be sold at $25 \mathrm{C}$ and aimed at the school market. This appears not to have been done. The House issued two further works by Traill, Canadian Wild Flowers (1895), and, after her death, Studies in Plant Life (1906). The former was likely a subscription publication while the latter - though it was issued on a royalty basis - appeared only after Traill's niece, Agnes Chamberlain (who was also the book's illustrator), had solicited advance subscriptions. ${ }^{89}$

In the years immediately following 1893 , the House published many books by minor and major literary figures. Among them were works of history, poetry, fiction, and religion. F.G. Scott's My Lattice, and Other Poems appeared in 1894, followed by J.W. Bengough's Motley: Verses Grave and Gay, W.H. Withrow's Barbara Heck: A Tale of Early Methodism, Egerton Ryerson Young's Oowikapun: or, How the Gospel Reached the Nelson River Indians, and E.W. Thomson's Old Man Savarin, and Other Stories in I895. In the following two years the House issued two more of Thomson's books, Walter Gibbs, the Young Boss and Other Stories (1896) and Between Earth and Sky (I 897). The publication of the latter merited comment from the Canadian Magazine: 'William Briggs . . . is to be congratulated upon this addition to his long list of Canadian books. ${ }^{\prime 9}$ Other books of interest published during these years include: Robin and Kathleen McFarlane Lizars's In the Days of the Canada Company (1896), John McDougall's Saddle, Sled and Snowshoe (1896), Charles G.D. Roberts's Around the Camp Fire (1 896) and Forge in the Forest (I 897), J.G. Hodgins's The Legislation and History of Separate Schools in Upper Canada (1 897), Theodore H. Rand's At Minas Basin, and Other Poems (1897), F.G. Scott's The Unnamed Lake, and Other Poems (1897), and Alexander Sutherland's The Kingdom of God and Problems of Today (r 898).

In 1898 the House issued Henry J. Morgan's biographical dictionary, Canadian Men and Women of the Times. A second edition of Morgan's work appeared in I9I2. Both editions emerged long after their initially projected publication dates. Described by Bookseller and Stationer as 'a work awaited with some impatience by an army of subscribers,' the first edition - advertised as a volume of 500 pages at $\$ 2.00-$ emerged as a lengthy $I, 200$ pages with a $\$ 3.00$ price tag. ${ }^{91}$ Subscribers were not pleased. In the case of the second edition, Briggs ultimately had to refuse to accept any more material from Morgan as production costs were going to exceed the amount that would be generated from sales. ${ }^{92}$ After its publication the House faced the embarrassing task of recalling page 94I of the book and 
issuing a replacement page as the original contained 'a libellous statement. ${ }^{193}$ Morgan died in arrears to the House in 1913, and Briggs had to confiscate unsold copies in lieu of payment.

In the early twentieth century history, fiction, and poetry made up a prominent part of the House's list. Works that appeared included Thomas O'Hagan's Songs of the Settlement, and Other Poems (r 899) and Canadian Essays, Critical and Historical (1901), George Bryce's The Remarkable History of the Hudson's Bay Company (1900), Agnes Laut's Lords of the North (I900), D.B. Read's The Lieutenant-Governors of Upper Canada and Ontario (1900), Charles G.D. Roberts's By the Marshes of Minas (1900), James Young's Public Men and Public Life in Canada (1902), John McDougall's In the Days of the Red River Rebellion (I903), Virna Sheard's By the Queen's Grace (1904), and Agnes Maule Machar's Mariorie's Canadian Winter: A Story of the Northern Lights (1906). Of special note is M.A. Brown's My Lady of the Snows (1908), the first Canadian work of fiction to contain colour illustrations drawn, engraved, and printed by a Canadian publishing house. 94

Poetry was not a lucrative area of sales, and, for that reason, the House approached its publication cautiously. In I 899, for example, Caswell's suggestion of republishing William Kirby's Canadian Idylls (it had been printed in Welland in r894) met a negative response. Caswell wrote to Kirby: 'How many copies have been sold? If there has not been more than 500 or rooo sold, it should pay you to republish. I will speak to Dr. Briggs \& Dr. Withrow about it. ${ }^{\prime 95}$ Despite Caswell's - and possibly Withrow's - persuasions, Briggs rejected the proposal:

[Dr. Briggs] could not see his way clear to assuming the cost of publishing the book. His faith in the selling properties of Canadian poetry, even with the prestige of your name, is not strong enough to induce him to venture a third edition. I certainly think that if you can arrange with us in some way, perhaps by payment of part of the cost in advance, that between us, our sales and yours, the edition would not be long in paying for itself. I do not feel like saying anything, however, that might be construed into urging you to proceed with the publication of the book when there is an uncertainty about its success commercially. ${ }^{96}$

By contrast, the House did issue The Poetical Works of Alexander McLachlan (1900), Charles Mair's Tecumseh, A Drama: and Canadian Poems (I90I), and William Wilfred Campbell's Poems (I905) 
on a royalty basis. McLachlan's work was a memorial volume of 424 pages containing an introductory essay, memoir, notes, and a glossary. E.H. Dewart, who had praised the poet in his anthology in I864, wrote the introductory essay. He argued that a 'regard for the common people' was the distinguishing characteristic of McLachlan's poetry and that '[f]or this cause, as well as for his extensive treatment of Canadian subjects, whether he conforms in all respects to the canons of the critics or not, this volume should be favorably received and widely perused by the people of Canada. ${ }^{97}$ Thus, Dewart felt that McLachlan's technical shortcomings as a poet should not obscure the important subjects he addressed, one of them being Canada. However, the volume did not sell well, and Bookseller and Stationer was forced to conclude that '[p]oets, like prophets, are not overburdened with honor in their own country. ${ }^{98}$

Charles Mair's efforts to get Tecumseh, A Drama; and Canadian Poems published further highlights the market for Canadian poetry near the turn of the century. The author initially submitted his manuscript to George Morang. ${ }^{99}$ Morang apparently refused to take on publication at his own risk. ${ }^{100}$ At George Taylor Denison's suggestion, Mair agreed that Denison might submit the work to the Methodist Book and Publishing House on the author's behalf. ${ }^{\text {ror }}$ (Denison acted as an intermediary for his Winnipeg-based friend.) The author wrote optimistically to Denison: 'I hope Mr. Briggs will take hold. ... I am sure that Mr. Briggs will not lose by the venture. For my own part I don't care if I get one cent out of it. But I feel sure there will be a good sale $\&$ that we shall both make something.' ${ }^{102}$ But the House was leery. Caswell wrote privately to Denison several weeks later:

This morning I have had a talk with Dr. Briggs, and with Mr. Gundy, the head of our Wholesale Department, and who arranges for many of our new books, over the proposed new edition of 'Tecumseh,' with Mr. Mair's later poems added. Neither Dr. Briggs nor Mr. Gundy felt that it would be a safe venture for the house to bring out any considerable edition of the book relying on the ordinary means of sale to remunerate for the cost of publication. There are, no doubt, a considerable number who take an interest in Canadian poetry, and who would be delighted to get a nice copy of Mr. Mair's poems, and the whole thing of course hinges upon how many of these there are. Possibly the whole number might not be more than 100 or $200 .{ }^{103}$ 
Caswell's realistic assessment suggests the smallness of the market for Canadian poetry that existed at the turn of the century and the caution that it engendered among publishers. He was equally discouraging about the House's ability to place copies with a British publisher:

It is possible that an English house would take a part of the edition, but our own experience in books that we have published is not very encouraging. We very rarely have been able to place copies of one of our books with English publishers. The Ward, Lock Company took Mr. Cumberland's 'Story of the Union Jack,' but it was largely to oblige Mr. Gundy that they did this, and they had to have it at a price that left nothing for the author. (This of course is strictly confidential. $)^{\text {IO4 }}$

In the end Caswell proposed an arrangement similar to the one he had offered Traill in I 894:

Dr. Briggs suggests that possibly Mr. Mair or those of his friends who are sufficiently interested, might do something in the way of securing advance orders. Suppose we were to print the title-page, table of contents, and probably half-a-dozen pages of matter to show the type, size of page, etc., and enter this in a note-book for the securing of subscribers' names. Do you think Mr. Mair would take one of these books himself and endeavor to get several of his friends to take books, so that a subscription list could be worked up that would make the publication less of a risk than it now is? ${ }^{\text {IO5 }}$

Caswell envisioned an edition of $\mathrm{I}, 000$ copies with a cost price of $60 c$ and a retail price of $\$ 1.50$. Three hundred subscribed copies, he felt, 'would place the venture beyond the region of risk. ${ }^{106} \mathrm{He}$ left it with Denison to make this suggestion if Denison thought the author would be receptive to it. ${ }^{107}$ Mair embraced the idea, confident of his ability to gain subscribers:

There is perhaps no one better known in the North West than myself, and I am constantly asked when my book is to be out. It is looked for, and though a chastened being, and not over sanguine now-a-days, still I think my book will touch sympathies and nerves and fibres Dr. Briggs does not wot of. ${ }^{\text {I08 }}$

Mair and his friends industriously set to work, and by December, when the volume was issued, there were more than 300 subscriptions. ${ }^{\text {IO9 }}$ 
Although he was grateful that Briggs had taken 'the book up,' Mair had a few criticisms of his publisher. Prior to the volume's publication, he grumbled to Denison over Briggs's wish to limit the number of portraits in the book (portraits were costly to reproduce), and he questioned the House's decision to give him only a ten per cent royalty on the copies sold by subscription. He felt this unfair given that the House was saving the bookseller's discount on those copies:

Mr. Briggs writes that the usual [royalty] percentage is $10 \%$. 'We could hardly,' he says, 'offer more on a book of this class. The only books that bring higher royalty are the popular novels.' If he means the copies sold by the booksellers I suppose it is all right, but surely I should have the bookseller's royalty on subscriptions obtained by my friends. ${ }^{\text {IIO }}$

Briggs's statement about royalties confirms the pre-eminence of fiction over poetry as a saleable commodity. Nevertheless, Mair must have come to some arrangement with Briggs; in a later letter he noted: 'The Booksellers are all ordering [in Winnipeg], but of course that does not mean much royalty for me.' ${ }^{\prime I I}$ Yet another revealed Briggs's lack of favour with the Winnipeg Free Press:

The Free Press here published a strong notice of the forthcoming book on Saturday. Mr. Briggs, tho', is not popular with them. It appears he does not advertise atall [sic], and runs on the cheap, having no canvasser here like Morang, who keeps the papers going. What they do is out of personal regard for me and not my publisher. ${ }^{122}$

Morang's presence in Winnipeg likely influenced Mair's initial decision to submit to that publishing house. One of Briggs's I9 I I contracts (albeit for a decidedly religious juvenile work) provides a list of journals in which the book might be advertised. The majority of these papers originated from Toronto and many among them were the House's own publications. ${ }^{113}$ Thus, Briggs may have considered advertising in the House's own periodical publications as the most affordable way of reaching readers across the country; however, Methodism's Ontario concentration inevitably would have made his promotional efforts most acute in Ontario itself.

The years around the turn of the century should also be noted for the publication of three Canadian poetry anthologies: $A$ Treasury of Canadian Verse (1900) edited by Theodore H. Rand, E.S. 
Caswell's Canadian Singers and their Songs (1902), and Mrs. C.M. Whyte-Edgar's $A$ Wreath of Canadian Song (I9I0). One critic later condemned Whyte-Edgar's volume as 'the worst Canadian anthology' he had ever seen. ${ }^{\text {II }} 4$ Caswell viewed $A$ Treasury of Canadian Verse as an important undertaking and actively pursued, on behalf of the book's editor, a reluctant William Wilfred Campbell for contributions:

I feel impelled ... to write you yet again re Dr. Rand's book. I need not say that it is of no moment to me personally (other than is dictated by the feeling of friendship for you) whether or not you appear in this book, but it does matter a great deal to you. Why are you so - pardon me if I use the only applicable word - obstinate? You are the only one who has refused permission, and every poet of any name or worth will be in this book. It is going to have a big sale. Lamson, Wolffe \& Co., of Boston, will issue it in England \& America, and we in Canada. We will probably print 2000 copies at the first.

Dr. Rand will in his preface have to regret his inability to secure permission to use any of your work - and why should you seek such unpleasant prominence? It will hurt you sure as you live. It is in your own interest I thus write you, and if after this appeal you still refuse I will say no more - I have done the whole duty of a friend.

Come down off your high horse! Make good your word to me when here, or - or - !!!

Yours with a last threat,

E.S. Caswell

Campbell remained unmoved, and Rand was forced to regret the omission of work by the poet in the preface to the volume. Campbell subsequently explained his refusal as a dislike for anthologies; however, the poet went on to edit two anthologies at a later date. ${ }^{\text {II }}$ Rand's preface also acknowledged Caswell 'for many courtesies, and specially for aid in procuring well-nigh inaccessible materials for examination. ${ }^{\text {II6 }} A$ Treasury of Canadian Verse obtained a steady sale in Canada - a second edition was published in I90I and over 2,000 copies had been sold by early 1904 . $^{117}$

Caswell's influence is again evident with respect to the collected verse of Isabella Valancy Crawford. While John W. Garvin served as the volume's editor, Caswell held some sway over its contents. Ethelwyn Wetherald, who wrote an introduction for it, was much 
distressed to learn from Garvin that Caswell insisted some of Crawford's lesser verse be included:

My heart sank when I heard that 'He saved his soul and saved his pork' was to go in after all. It is a case of where the evil that women do live after them and also goes to prove that even the most careful and critical of Editors (as yours undoubtedly are) is yet in spite of himself compelled at times to play the gallery.

And yet I can perfectly understand Mr. Caswell's reasons. He knows, of course, that in many Canadian houses where the first book of Isabella's is valued the dialect 'poems' are probably regarded as gems of genius, and a perfect howl could be raised if in what purposed to be her 'complete' works, the said (master) gems were omitted. You and I have been working to suit our own taste, but the publisher must consider that of his least tasteful readers. ${ }^{\text {II } 8}$

As had been the case with Mair's work, Caswell took into consideration his potential market. However, the use of an external editor and the inclusion of a critical introduction from a member of the Canadian literary community was also illustrative of a more academic approach to the work's publication. It followed the pattern earlier established in the publication of McLachlan's poems. By contrast, The Poems of Archibald Lampman, which Morang issued in I 900 under the editorship of Duncan Campbell Scott, contained a biographical memoir of Lampman but no critical evaluation of his work. The House would subsequently issue Pauline Johnson's The Moccasin Maker (1913) with an introduction by Sir Gilbert Parker and an appreciation by Charles Mair. Parker offered Johnson's work measured praise but emphasized that she was no genius and firmly established her as a minor poet; amusingly, three pages later Mair opined that '[i]n the death of Miss Johnson a poet passed away of undoubted genius.' ${ }^{\text {Irg }}$

Writing in 1935 Garvin stated that Crawford's Collected Poems sold 600 copies within a few weeks of publication. ${ }^{\mathrm{I}}{ }^{20}$ More contemporary evidence challenges that claim. Caswell wrote Garvin in April I 907, for example, stating that only 47 I copies had sold during the sixteen months since its release. ${ }^{\text {I2I }}$ The Canadian Magazine, in turn, reported that the collection had met with critical success but had not achieved a large sale:

[A]lthough Isabella Valancy Crawford's complete volume of poems has been published a year and a half, less than five hundred copies have been sold. It is really inconceivable that a volume of poetry of 
such qualities, which has won lengthy eulogiums from the critics, should find so inconsiderable a sale. ${ }^{\mathrm{r} 22}$

The journal linked this poor reception to an education system that did not validate Canadian literary effort through inclusion of Canadian literature on the curriculum:

Evidently what is needed is more attention to be given to our Canadian writers in the schools and colleges. Why should the work of the classes in literature be confined to the English and American poets, and our own be neglected? It is time our educationalists woke up to the fact that we have a literature well worthy of study. Perhaps that will come when more of the native-born begin to fill our professional chairs. ${ }^{123}$

By the time the Canadian Magazine made this statement some academic interest had been expressed toward Canadian writing. Indeed, the House had already issued C.C. James's $A$ Bibliography of Canadian Poetry (1899), L.E. Horning and L.J. Burpee's A Bibliography of Canadian Fiction (1904), James Cappon's Roberts and the Influences of his Time (1905), and Archibald MacMurchy's Handbook of Canadian Literature (1906). In 1897 it also began issuing the annual Review of Historical Publications Relating to Canada, which was edited by George $M$. Wrong of the University of Toronto. (It was subsequently printed by Morang from I904 to I 908 and then the University of Toronto Press.) MacMurchy's 'Handbook,' Bookseller and Stationer argued, would be 'hailed with satisfaction by instructors in public and high schools, who long have felt the need of such a work.' ${ }^{\prime 24}$ Horning and Burpee's effort was paid for by the library committee at the University of Toronto; typically, Caswell was 'extremely obliging' and provided helpful advice on its compilation. ${ }^{25} \mathrm{He}$ also lent proofs of the book to John A. Cooper, who had expressed an interest in the work. ${ }^{126}$ Cooper, then editor of the Canadian Magazine, considered it valuable though not as complete as it could be - and offered to facilitate the further gathering of information about authors through a note in his magazine. ${ }^{127}$ This interaction between Caswell and Cooper offers a brief glimpse of two important turn of the century editors working to the benefit of one another's endeavours and to the promotion of indigenous writing. It also hints at the literary network of which Caswell - both vis-à-vis his position at the House and his own personal interests - was a part.

At the turn of the century the House published what proved to be 
several bestselling works by Canadian authors, including W.A. Fraser's The Eye of a God (1899), Ernest Thompson Seton's Two Little Savages (1903), Arthur Stringer's The Silver Poppy (1903), and Nellie McClung's Sowing Seeds in Danny (1908).128 Robert W. Service also exploded onto the scene in 1907 with the publication of Songs of a Sourdough. Information surrounding the publication of the latter two books provides some insight into the House's book publishing in these years.

McClung's Sowing Seeds in Danny had a sale of several thousand copies in its first year. Although the book did not appear until three years later, the author actually started corresponding with the House in I905. Initially McClung sent a short story to W.H. Withrow, with whom she had had previous contact through her contributions to the Sunday school paper, Onward. The House wrote back encouragingly in July of that year, asking her to expand the story into a longer work, expressing faith in her ability to do so, and suggesting that it 'might perhaps be better business policy to contribute a few short stories such as these to the Magazines, or large weeklies, American as well as Canadian, in order to get your name favourably known to the public. ${ }^{129}$ The letter also asked McClung's permission to submit the story 'to some whose judgment we have confidence in, and see what they think of it.' ${ }^{130}$ Although signed 'William Briggs,' its detail and inclusion of literary commentary suggest it was actually written by Caswell. In two subsequent letters, presumably in response to her queries, she had explained to her the publishing practices of the day. On 3 I July I 905 the House wrote:

As regards the publication of a story of this kind we would say that our general rule is not to purchase any manuscripts whatever and we may say that most of the stories published in Canada are issued at the entire risk of the author, that is the author pays for the manufacture of the book, that is the printing, binding, etc, and the publisher markets the book for the author. ${ }^{13}$ I

followed on I 2 September I 905 by:

Your letter raises the question of whether or not you may be depending upon us to accept the story for book publication when it is written. We could not promise to do this. The little story that you sent us down here ... impressed our Reader and a number of others who have since read it, as exceptionally clever and good, but the 
cost of setting the type and binding and placing the book on the market is so great that it does not pay us to publish a story from the original manuscript for the Canadian market alone. If an American publisher can be interested, - and we think you can write to interest one - that big market offers a very attractive field. The stories that we publish at our own cost are in reality reprints from imported plates of English or American books. We can procure the plates very much cheaper than we can set the type. ${ }^{\mathrm{I} 32}$

The economics of producing for the Canadian market had made it common practice for Canadian publishers of the period to borrow plates or import the work in sheets or bound volumes from American and British publishers. Briggs reiterated this position several years later in a letter to Hiram Cody, who had approached the House about publishing God's Frontiersman. He also explained at that time: 'It may be that when we come to read this story of yours we may see that it would have a good chance with an American or English publisher, and in this case we might do something for you toward getting it placed abroad, we handling the Canadian edition.' ${ }^{133}$

One can only wonder about how placing the manuscript with a foreign publisher may have affected such Canadian-authored titles. To what degree, for example, were the manuscripts edited to meet the expectations of a foreign readership? Susanna Moodie certainly bore an English readership in mind when she reworked Canadian sketches for inclusion in Roughing It in the Bush, which was published in Britain in $1852 .{ }^{134}$ In her revisions she adopted a 'more high-toned and poetic' language and excised some passages 'presumably to protect the sensibilities of her English and feminine audience.' ${ }^{135}$ Moreover, Charles Frederick Briggs, in editing Moodie's work for American publication, deliberately removed 'certain passages of a purely personal or political character, which could have possessed no interest for the American reader.' ${ }^{136}$ Furthermore, in I89I E.W. Thomson complained of having trouble placing one of his short stories with American magazines because it was 'too local in interest.' He continued:

We Canadians are a good deal hampered by the lack of literary publications in our country, for, in appealing, by fiction, to foreign audiences we are required not only to drop out much racy of the soil and to refrain from merely allusive remarks that would instantly be understood in Canada, but also to place ourselves mentally in the place of the foreign reader. It is writing in hobbles. ${ }^{137}$ 
Assessing to what degree Canadian authors whose work was placed with foreign publishers may have felt themselves to be 'writing in hobbles' remains a speculative venture. ${ }^{138}$

Caswell was enthusiastic about McClung's work and about its chances for American publication. Indeed, his expectations for the book were so great that he even offered to go into partnership with her:

I wonder if you'd care for a partner in the story? I've been thinking it over, \& I'd like to give some chances on it. Will you consider this proposition - that I pay you $\$ 200$ cash now and do what I can to place it with our House and with an American publisher, on the best terms I can secure, and we divide the royalty between us. I feel certain I can secure an American publisher for the book, and I think our House is sure to take the Canadian market. The head of our wholesale department, Mr. Walker, who handles our fiction is now reading the MS. with this in view. I can hardly conceive of his turning it down, though he is extremely cautious. ${ }^{139}$

McClung accepted Caswell's proposition. Given his employment with the House, the ethics of his arrangement with McClung were certainly questionable. However, the general condemnation both his character and his literary advice has received at the hands of McClung's most recent biographers ${ }^{140}$ ignore both the book publishing and literary climate of the day and, perhaps most importantly, McClung's own later assessment of him as her 'patient, wise, encouraging counsellor. ${ }^{\prime 4}{ }^{\mathrm{I}}$

By early 1908 an American publisher, Doubleday, Page \& Co., was found. Although the American publisher, like Caswell, had faith in McClung's book, Walker had doubts. In subsequent letters to McClung, Caswell expressed frustration over his colleague's obtuseness and lack of imagination:

Mr. Walker evidently has but small faith in the book as a 'seller.' ... his attitude is in this case just what it has been toward every MS. I've shewn him. Were he only to be considered I'd waste no thought on him, but if he can be got to take the book he can do more for it - or we can, with all our departments - than I think any other firm can.... If Gundy were in Walker's place he'd buy a set of plates, $\&$ that's what we should do. ${ }^{142}$

Caswell's fundamental problem was that he had to work in tandem with other departments to get a book published. His own department - focussed in editorial and promotional work — had neither 
the financial ability nor the mandate to produce books at its own risk. Thus, he quite literally had to convince his colleagues of a manuscript's worthiness before it could be produced.

In April 1908 Walker wrote McClung that the House would pay her a ten per cent royalty, that they planned to purchase copies of the work from Doubleday, Page \& Co., and that they would place an initial order of 500 copies. ${ }^{143}$ Caswell was not impressed with a paltry book order of 500 copies. In (what appears) an attempt to allay some of the fears he had inspired in McClung with his references to Walker, he wrote on I6 May I908:

Walker promises to push the book, and he perhaps will - certainly he will if he finds it a 'seller' - he'll be keen enough then. But he is very cautious. As for giving the book publicity this is in other hands. Our advertising man [F.S. Ewens] will see that it gets due advertising \& I will look after reviews $\&$ do a good deal in getting it before the public. Don't imagine the book is going to be thrown down by us. No fear of that, but I could wish Walker had a more robust faith in the book $\&$ would order more than 500 copies....

Walker's attitude toward the book is just what he maintains toward all my new $\&$ untried authors. They have to prove their innocence of being frosts $\&$ failures before he will give his faith to them. ${ }^{\mathrm{I} 44}$

While highly suggestive of the tension existing between Walker and Caswell, this letter also reveals how the efforts of a number of individuals came into play in the promotion of a book. F.S. Ewens, for example, was as enthusiastic as Caswell about Sowing Seeds in Danny and earnestly pursued its promotion. R.B. Bond, one of the travellers, also took a strong interest. Caswell continued to express his displeasure with Walker, writing to McClung in September:

We have been now for several days without a single copy of the book. It is provoking beyond description. I am sorry Mr. Walker's attitude towards the book is not more friendly. Perhaps I am unjust in thinking that he is not friendly towards it. It may all be merely a matter of super-caution on his part, but his second order for 250 copies seemed to me so insufficient, to say the least, that I could not understand it. I never would have recommended you to give the book to Mr. Walker only that I knew the opportunities that some of us in other departments would have for booming the book, and you may rest assured we will give it every chance. ${ }^{I 45}$ 
The following month Caswell happily announced the 'awakening of E.W.W.'I46 Orders had begun to pour in rapidly and, thus encouraged, Walker had begun to pursue the book's sale more forcefully. McClung subsequently published The Second Chance (1910) and The Black Creek Stopping-House, and Other Stories (I9I 2 ) with the House. Caswell continued to correspond with McClung after he left the House in October 1909 and offered her extensive editorial advice on the writing of The Second Chance.

Amid the preparatory work surrounding Sowing Seeds in Danny, the House published Robert W. Service's Songs of a Sourdough in 1907. It proved a financial boon for the establishment. Over the next several years the trade journals sporadically mentioned sales figures for the book; in February 1908 the Bookseller and Stationer reported that it was going into its ninth edition, and in January 1909 the Canadian Bookman noted that Songs of a Sourdough had achieved a sale of over 28,000 copies. ${ }^{147}$ The work appeared in paper, cloth, and illustrated editions.

Service originally sent his manuscript to the House with a $\$ 100.00$ cheque, asking that it be printed. Caswell, who received the manuscript, duly set about having the book made up. He then gave a copy of the proofs to R.B. Bond, requesting that he try to get some orders for it while on his sales trip in the West. ${ }^{148}$ While Bond was away, Songs of a Sourdough was submitted first to the wholesale department and then to the library department to see whether either would like to take it on. (Both these departments had the option of publishing a work at their own risk.)

Walker's caution again came into play with this work. John McClelland, who headed up the House's library department (it served libraries and Sunday schools), thought the book had potential. McClelland, whose position included reading and editing manuscripts as well as selecting and selling books to libraries, later recalled:

I had something to do with the publication of the original Service book and know the facts concerning that book. . . It was the custom of the House that new books were submitted to the trade department, which was done in the case of Songs of a Sourdough and it was turned down by Mr. Walker's Department. Mr. Caswell, who was the literary editor, turned the manuscript over to me and I decided to take it for our Department, for I could see the possibilities in it. It just so happened, however, that at this particular time, the Western representative of the Trade Department, Mr. 
Bond, was in the West and he heard here and there reports of the work of Service and he wrote his chief, the result being that the book was taken again to the Trade Department and finally accepted by them. Mr. Caswell and myself were of a decided opinion that the book was one that was sure to have a book [sic] sale but the others, at the time, could not see it. $^{\text {I49 }}$

Walker later claimed that he had seen its 'saleable qualities' immediately. ${ }^{150}$ In 1958 R.B. Bond offered his own version of the facts about the book's publication, recalling that his reading aloud of one verse to a fellow salesman on the train led him, later that day, to try more of Service's work on a car full of people. In a bid to generate orders from booksellers he continued to read Service's work whenever and wherever he could during the remainder of his western trip:

It was in Revelstoke, a railway town in British Columbia, that I received my first sample copy of Songs of a Sourdough. . . . How I swore! It was a poor-looking, thin book, bound in green cloth, marked Author's Edition. But more important to me than its appearance was its price. It was listed at 75 cents retail. I was indignant. I wrote immediately to William Briggs, stating that I had been selling it as a $\$$ I book, retail. Furthermore, I said, if the office people would check their orders they would see that the first edition must be just about sold out. And I offered the opinion that it was the first book of Canadian poetry we'd published that had good commercial possibilities, and we should own it on a royalty basis. ${ }^{\text {I }}$ I

The House followed Bond's advice, offering Service a 254 royalty per copy on the first edition of 500 copies and after that ten per cent on retail. ${ }^{152}$

Given the nature of some of the verse in Songs of a Sourdough, it is likely that the House may have met with some criticism for publishing and selling it. According to J.D. Logan, the House had doubts about issuing it. Prior to its publication Caswell gave him a copy of the proofs to read and asked him whether 'the House should "risk" (morally risk) putting out such a book with the firm imprint.' As a result, the first edition 'bore on the imprint "Author's Edition. William Briggs. Toronto, I907" ' and

as soon as the press copies of this small 'privately printed' edition were flatteringly reviewed by the press and it was seen that a 
so-called 'Canadian Kipling' had arrived and that The Church would not attack the young poet, the publishing House, with business shrewdness, removed the words 'Author's Edition' and published subsequent editions with the firm imprint. ${ }^{153}$

In his biography, Ploughman of the Moon, Service recalled that his second effort, The Ballads of a Cheechako, also caused the House some anxiety. After seeing the manuscript the House wrote Service that it was loathe to publish the new work as it stood. Service responded angrily, telling them to pass the manuscript along to another publisher:

In their first letter they had complained of the coarseness of my language and of my lack of morality. As a highly respectable firm with church connections they thought its publication would reflect discredit on their reputation. Also on my own. They suggested I scrap the book and write another of purer tone. Now, however, with my threat of publishing elsewhere, they entirely changed their position. They begged me to make certain minor changes, and to leave out one particular ballad dealing with the Tenderloin.

I thought it great fun pitting one publisher against another. Cynically I sat back and enjoyed myself. I wrote, pointing out that I had no reputation to consider, and that morality had nothing to do with literature. However, I wanted all my work to appear under the one imprint, so I said I would remove the offending ballad, but it would cost them five per cent more royalty. It did. ${ }^{54}$

In the years immediately following, the House issued Service's The Trail of '98 (I9II), Rhymes of a Rolling Stone (1912), The Pretender (1914), and Rhymes of a Red Cross Man (1916). The Pretender too was subject to some revision. In the early I 920 W William Arthur Deacon divulged to E.J. Pratt:

[E.J.] Moore confided in me what a stunt he had pulled some years ago. The house was bringing out the Canadian edition of Robert Service's 'The Pretender.' Dr. William Briggs was persuaded by Moore that a section of the book was pornographic, and could not appear in Canada. So he wired Service in Paris asking permission to make 'slight alterations'. Permission received. Moore deleted five chapters, and himself wrote five new chapters to be substituted. Then he rushed to New York and got Dodd, Mead \& Co. to make new plates for the new chapters, which was done. ${ }^{155}$ 
The Canadian edition appeared with the following note: 'In deference to the opinion of the publishers the Author has consented to certain alterations being made in his work. ${ }^{156} \mathrm{~A}$ comparison between the American and Canadian editions does reveal changes in five chapters; however, to describe those alterations as a complete rewriting of the chapters in question is exaggeration in the extreme. One example of altered text appears at the beginning of the chapter, 'City of Love.' The two editions read as follows:

American:

Now the Crystal Palace is one of these traps for the unwary stranger with which Paris is baited. You are ushered into a brilliantly lit room, whose walls and ceilings are made of mirrors. Presently the door opens, and in troop five girls, clad only in tambourines, who straightway proceed to dance a tarantella. At its conclusion you are asked to buy them champagne, and you are indeed lucky if you get out of the place under a hundred francs. Half of this goes as commission to the guide, a gang of whom infest this particular corner. ${ }^{157}$

\section{Canadian:}

Now the Crystal Palace is one of these traps for the stranger with which Paris is baited. Your Parisian knows these places as part of the city's life which is not there for the Frenchman but for the tourist and the stranger. These people look for these things as a part of the life of Paris, your Parisian says, and in consequence they are there. ${ }^{158}$

Textual differences also appear in the chapters, 'The City of Light,' 'The Stress of the Struggle,' 'The Dawn,' and 'The Great Quietus.'

The last ten years of Briggs's tenure have been noted as a period of decline in the House's publication of Canadian authors. ${ }^{159}$ However, in the years between I9IO and I9I4 the House continued to publish annually between fifteen and thirty new Canadianauthored titles. ${ }^{160}$ Included among them were works by notable authors. Along with McClung's and Service's works, books by Hiram Cody, Katherine Hughes, John Daniel Logan, Ernest Thompson Seton, Robert J.C. Stead, Agnes Maule Machar, Agnes Laut, and Thomas $\mathrm{O}^{\prime}$ Hagan appeared. Most of these authors had begun publishing with the House before 1909 when Caswell headed the 
book publishing department. After he left, Ewens apparently did a satisfactory job of maintaining these writers. Certainly, his letters to McClung were helpful and supportive. After I9I4, the year of Ewens's death, the House's list grew much skimpier, and, over the next several years, the more prominent Canadian writers began to disappear from it. One of the few memorable titles to appear was John McCrae's In Flanders Fields, and Other Poems (1919), which became a bestseller in three countries. ${ }^{\text {I6I }}$

Some insight into the decline of the House's book publishing emerges from Robert J.C. Stead's correspondence with his British publisher, T. Fisher Unwin. In I9r4 Unwin agreed to publish The Bail Jumper with Briggs taking the Canadian edition. Stead had a relationship of several years standing with the House, it having produced editions of his earlier works, The Empire Builders (1908), Prairie Born, and Other Poems (I9II), and Songs of the Prairies (I9II). The Bail Jumper did not meet with good sales, and Briggs declined to take the Canadian edition of Stead's next book, The Homesteaders, citing 'the bad conditions of trade in Canada. ${ }^{162}$ On I 2 September I9 I 5 Stead wrote to Unwin:

I may now confess that I have felt that The Bail Jumper didn't get much of a chance in this country. I have the kindliest relations and personal feelings for Dr. Briggs and his associates, but I am convinced that their policy is more to handle staples in fiction, if I may use the term, than to develop new producers of their own. I sold four thousand copies of my first book of verse myself, almost exclusively by mail, and could have sold as many more if I had had time to devote to it, and yet Dr. Briggs complains that he lost on one thousand Bail Jumpers! Do you know that, so far as I have been able to learn, Dr. Briggs secured a total of three reviews of 'The Bail Jumper' in all Canada? I personally secured $2 \mathrm{I}$ reviews, and could have had many more, but Dr. Briggs declined to supply me with copies for review purposes unless I bought them. The sales campaign seems to have been no more aggressive. At Christmas time I found booksellers in some of the largest towns in Alberta - one of the biggest stores right in my own city, for instance - who had never been canvassed, circularized, or approached in any way in connection with my book. I mention these matters, not in a carping spirit, but as some explanation of why business has not been good. ${ }^{163}$

If Stead's revelations to Unwin are reflective of the House's book promotion in the later years of Briggs's tenure, then it is not 
surprising that such a notable decline took place. Moreover, his belief that the House focused on the 'staples of fiction' stands in sharp contrast to earlier years when the House received praise for its endeavours to publish and promote Canadian authors. By I9 IO, Briggs had joined Canadian publishers like Copp, Clark and The Westminster Company in 'cashing in on a good thing' by reprinting old and successful titles. ${ }^{164}$ The House's reprint series rose from twenty-three fiction titles in I9I 2 to 127 titles in I9I3, and included works by such popular Canadian authors as Hiram Cody, Ralph Connor, Agnes Laut, Nellie McClung, and Robert Service. ${ }^{165}$

In The House of Ryerson Lorne Pierce offers his own assessment on the lack of book publishing undertaken during the later years of Briggs's term:

During the last decade of the regime of Dr. Briggs the book publishing programme of the House gradually slowed down to almost zero. The House had taken on a large number of important foreign agencies, which provided each year roaring sales of best-sellers from New York and London. It was a time when the trade departments dominated the policy of the House. If agency titles could be had, with little or no risk, why waste time and money on Canadian ventures? ${ }^{166}$

While his statement that the trade department dominated the policy of the House supports Stead's assessment of the situation, Pierce's comment regarding the publication of Canadian authors demands some clarification.

During this period a great deal of time and effort was spent producing a new Methodist Hymn Book. The vastness of this undertaking would have mitigated against the production and promotion of other works. The House took from the spring of I9I5 to the fall of 1917 to build up sufficient stock for its initial issue. ${ }^{167}$ These efforts were hampered by war conditions which created a 'scarcity of expert labor.' ${ }^{\prime 68}$ By late November I9I7 the House had shipped 50,000 copies of the 'words only' edition and 12,000 copies of the 'music' edition. ${ }^{169}$

The decline in the House's book publishing also had a strong connection to the House's loss of important members of its staff. S.B. Gundy left in 1904. W.H. Withrow died in 1908. E.S. Caswell joined the Toronto Public Library in 1909, and his successor, F.S. Ewens, died in r9I4. After Ewens's demise, for example, advertisements highlighting Canadian authors and Canadian books 
which had regularly appeared in the Christian Guardian for some years all but ceased. Ironically, through the war years the adjective 'Canadian' would come to dominate the advertisements of other Canadian publishers, ${ }^{170}$ echoing the practice of the House in earlier years.

After the turn of the century the House also faced keener competition, a portion of it generated by some its more gifted former employees. McClelland, Goodchild, and Stewart, for example, was recommended to Robert J.C. Stead 'as being enterprising, with a good connection with Canadian trade. ${ }^{171}$ Ironically, as the House's own commitment to Canadian writing was on the wane, other Toronto publishers began to express an interest. Cassell in I 9 I I and J.M. Dent in 1913 announced their intention to publish Canadian writing while Musson and McClelland, Goodchild, and Stewart slowly began to accumulate a 'roster of Canadians. ${ }^{172}$ Against the remonstrances of London head office, Frank Wise, manager of the Toronto branch of Macmillan, also pursued an interest in Canadian writing. ${ }^{173}$ In a striking parallel to the implicit mandate that had prevailed through the peak years of Briggs's stewardship, Wise's 'publishing programme was aimed at the development of Canadian nationhood.' '174

Finally, in the last five years of Briggs's tenure a cautious E.W. Walker and E.J. Moore, a man of questionable competence, headed the two most important departments related to book publishing within the establishment. During this same period the Book Committee was recording troubles in other areas of the House's activities. All of these circumstances contributed toward the decline in the House's publication of Canadian-authored titles. Ironically, given that decline, the Book Committee Report of 1918 argued: 'It is not the policy of the Book Room to be solely or primarily a money-making institution. Our endeavor, in developing the field of Canadian literature, is to encourage the publication of books of literary merit and to foster an appreciation of our own domestic talent whenever a legitimate opportunity offers. ${ }^{175}$ The Book Committee had fallen back on an old habit of emphasizing the House's cultural imperative when profits were down; significantly, however, the imperative it articulated had shifted from the dissemination of moral literature to the development of Canadian writing.

An exploration of the Methodist Book and Publishing House's book publishing practices during William Briggs's stewardship reveals that an immediate expansion in book publishing took place after his arrival. It was not until I893, however, that secular book 
publishing and a commitment to Canadian writing emerged as an important aspect of the House's operations. So it remained until I9I4. Coincident with this period was the presence of a number of talented and committed individuals - particularly E.S. Caswell, W.H. Withrow, and S.B. Gundy - to whom much credit must be given for the book publishing initiatives undertaken. This is not to belittle the role of William Briggs himself, whose endorsement was integral to their efforts. All the same, while the literary nationalism prevailing at the time may have fueled their collective enthusiasm, the political and economic realities of the Canadian book market constrained their endeavours and ambitions in this direction. As is clearly evidenced in existing information relating to books published during Briggs's tenure, the expense of publishing books by Canadian authors was always a concern, and the cost of doing so was more often than not absorbed in one way or another by the writers themselves.

The House could afford to pursue some indigenous book publishing because of the financial returns generated by the House's other activities. Moreover, the Christian Guardian and the periodicals served as important marketing tools while the Methodist constituency existed as a solid market base. Though the House's pursuit of book publishing and its commitment to Canadian writing were not provoked by an official edict of the church, Canadian Methodism's identification of itself as a nation builder granted those activities an implicit sanction. At the same time, book publishing's lack of status - aptly illustrated by the church's non-creation of an official book editorial position and by the lack of discussion it garnered at Book Committee meetings - provided it with no justification for generating a loss. Had the church given book publishing an official status and the House's encouragement of Canadian writing an explicit sanction, it is probable that a greater degree of risk-taking would have been undertaken on behalf of Canadian writing.

The decline in the House's publication of Canadian-authored titles in the later years of Briggs's stewardship was followed in the early 1920 s by a period of rebuilding and of new initiatives. Reverend Samuel Fallis, who succeeded Briggs as Book Steward in July r919, immediately changed the House's trade imprint to 'The Ryerson Press' and the following year recruited Lorne Pierce, an ordained Methodist minister, to serve as the House's 'Literary Critic and Adviser.' In placing book editorial work under the supervision of a clergyman, Fallis effectively gave book publishing a semiofficial status. Two years later the House adopted its first formal 
literary policy. By the time of the union of the Methodist, Presbyterian and Congregational churches in 1925, the House had reemerged as a recognized publisher of Canadian writing.

\section{RÉSUME}

L'édition de livres entreprise par la Methodist Book and Publishing House devint une activité beaucoup plus importante après que William Briggs assuma le poste de Book Steward en I 879. À l'aide de la documentation disponible relatif aux titres d'auteurs canadiens publiés par la Maison entre I879 et I9I9, cet article retrace le mouvement de cette maison d'édition de la production d'ouvrages à caractère principalement religieux vers la publication d'ouvrages canadiens d'intérêt plus général. En même temps, la documentation disponible, en particulier la correspondance, détaille le fonctionnement interne de la Maison en ce qui concerne les tentatives éditoriales et de promotion en même temps que les relations qui existaient entre les employés impliqués dans les efforts d'édition.

L'édition laïque et un engagement envers l'écriture canadienne devinrent particulièrement importants durant la période $1893-$ 1914. Durant cette période, un certain nombre d'individus talentueux et engagés étaient à l'emploi de la Maison, dont E.S. Caswell, W.H. Withrow et S.B. Gundy; ensemble ils travaillaient vers $1 a$ production et la promotion de l'écriture canadienne. L'approbation de William Brigg fut une partie intégrante de leurs efforts. De toute façon, il en ressort que la coût de publier des livres canadiens fut toujours une préoccupation et qu'il fut souvent absorbé par les auteurs eux-mêmes. De plus, pendant que le Méthodisme canadien, s'identifiant comme un bâtisseur de pays, donnait à la littérature canadienne un encouragement sans précédent, l'échec de l'Église d'accorder au secteur de l'édition un statut officiel laissa celui-ci générer une perte sans justification. Pendant les cinq dernières années de la direction de William Briggs, la publication de livres canadiens de la Maison chuta; des difficultés financières dans d'autres portions de l'entreprise et la perte d'employés clefs du secteur de l'édition de livres accentuèrent ce déclin. Au début des années 1920, sous la direction de Samuel Falks et la direction éditoriale de Lorne Pierce, la Maison commença à rebâtir sa réputation comme éditeur important de livres issus de la plume d'écrivains canadiens. 


\section{NOTES}

I Cited in Robson Black, 'Hours with Nation Builders: William Briggs,' Tribune (Winnipeg), I I October I913, Section 2, p.I.

2 Book Committee Minutes of 6 August 1879, Board of Publication Papers, Archives of the United Church of Canada/Victoria University in the University of Toronto. Unless otherwise indicated, all references to archival papers are to this collection.

3 Book Committee Minutes of 6 August 1879 .

4 Christian Guardian 50 (17 September 1879): 304 .

5 Book Committee Minutes of 16 May 1883.

6 William Briggs, 'Cyclopaedia of Methodism in Canada,' Christian Guardian 73 (26 March 1902) : 208.

7 See Janet B. Friskney, "Towards a Canadian "Cultural Mecca": The Methodist Book and Publishing House's Pursuit of Book Publishing and Commitment to Canadian Writing 1829-1926' (Master's thesis, Trent University, 1994), 88-9.

8 Minutes of Conference, 1837 . The Minutes of the Annual Conferences of the Wesleyan-Methodist Church in Canada from 1824 to 1845 , Inclusive; with Many Official Documents and Resolutions Not Before Published (Toronto: Anson Green, Conference Office, 1846$), 157$.

9 'The Book Committee,' Christian Guardian 5 I (18 February I880): 52.

Io Quadrennial Report of the Western Section of the Methodist Book Committee in the City of Toronto to the General Conference of the Methodist Church of Canada for the Year 1882 (Toronto: Methodist Printing and Publishing House, I882), I2, box 5 .

I I Withrow to Kirby, 7 February I 878, William Kirby Papers, Archives of Ontario.

I2 See Ken McLean, 'Evangelical and Ecclesiastical Fiction,' Journal of Canadian Fiction 2 I (1977-8) : 105-19.

I 3 W. Stewart Wallace, The Ryerson Imprint (Toronto: The Ryerson Press, 1954), 23.

I4 'Rose, George Maclean' in A Cyclopedia of Canadian Biography (Toronto: George Maclean Rose, I 888), 73 I.

15 Withrow to Kirby, I 9 January I880, Kirby Papers.

I6 Withrow to Kirby, 2 March 1880 , Kirby Papers.

I7 Ibid.

I 8 'John Cornwall Berkinshaw' in Commemorative Biographical Record of the County of York Ontario (Toronto: J.H. Beers \& Co., 1907), 370.

I9 See George L. Parker, The Beginnings of the Book Trade in Canada (Toronto: University of Toronto Press, I 9851, 196-201; and Alexander H. Brodie, 'Subscription Publishing and the Booktrade in the Eighties: The Invasion of Ontario,' Studies in Canadian Literature 2 (winter 1977) : 95-I01.

20 Parker, The Beginnings of the Book Trade in Canada, 195-196.

2 I Ibid., 196.

22 Ibid., 197.

23 Ibid., 198. 
24 John C. Berkinshaw was still managing the department in 1909 . However, no mention of a subscription book publishing department appears in articles which discuss the House after its move in 1915.

25 See advertisement for this book at the back of Egerton Ryerson, The Story of My Life (Toronto: William Briggs, 1883 ).

26 See reviews at the back of Ryerson, The Story of My Life and Quadrennial Report of the Western Section of the Methodist Book Committee in the City of Toronto to the General Conference of the Methodist Church of Canada for the Year I882, I3.

27 Carl Berger, The Sense of Power: Studies in the Ideas of Canadian Imperialism I867-1914 (Toronto: University of Toronto Press, 1970), 81 .

28 Ibid., 78.

29 See advertisement at the back of Ryerson, The Story of My Life.

30 C.B. Sissons, Egerton Ryerson: His Life and Letters (Toronto: Clarke, Irwin, Oxford University Press, 1937l, vii.

3 I Wallace, The Ryerson Imprint, 28.

32 William Briggs Agreements, Agreement \#233, box 9.

33 Report of the Western Section of the Book Committee of the Methodist Church to the General Conference 1886, p.19, box 5 .

34 Parker, The Beginnings of the Book Trade in Canada, 179-83.

35 Ibid., 182.

36 Emily McManus, 'O'Hagan's Poems: A Study,' Canadian Magazine I (October I 893) : 665-8.

37 Notebook of Costs of Various Printed Materials I88I-1890, box 3.

$38 \mathrm{Cal}$ Smiley, 'Adam, Graeme Mercer' in Oxford Companion to Canadian Literature, ed. William Toye (Toronto: Oxford University Press, 1983), 5.

39 G. Mercer Adam, 'An Outline History of Canadian Literature,' in W.H. Withrow and G. Mercer Adam, An Abridged History of Canada Also an Outline History of Canadian Literature (Toronto: William Briggs, 1887), 184 .

40 'Book Notes,' Books and Notions 9 (June 1893): 22.

4I 'Book and Literary Notes,' Books and Notions 9 (April r893): 8. See also 'Three Volumes of Poetry,' Books and Notions 9 (October r 893): 12.

42 Parker, The Beginnings of the Book Trade in Canada, 209.

43 George L. Parker, 'Publishing in Nineteenth-Century Canada: Copyright and the Market for Books' in Questions of Funding, Publishing and Distribution eds. I.S. MacLaren and C. Potvin (Edmonton: The Institute, 1989), 64.

44 Books and Notions 9 (July I 893): 22.

45 Margery Fee, 'English-Canadian Literary Criticism, I890-1950: Defining and Establishing a National Literature' (Ph.D. diss., University of Toronto, I98I), I.

46 Report of the Western Section of the Book Committee of the Methodist Church to the General Conference I894, p. 4, box 5 .

47 H.Pearson Gundy, ed., Letters of Bliss Carman (Kingston and Montreal: McGillQueen's University Press, 1981), 58.

48 Helen Lynn, ed., An Annotated Edition of the Correspondence Between Archibald Lampman and E.W. Thomson 1890-1898 (Ottawa: Tecumseh Press, 1980), I67, 172 . 
49 Duncan Campbell Scott to Copeland and Day, I3 March I 896, file 6, box 16.

50 Parker, The Beginnings of the Book Trade in Canada, 236.

5I 'About New Books,' Canadian Magazine 25 (October 1905) : 582.

52 See William Briggs Agreements, boxes 6-9.

53 J.C. Berkinshaw to William Canniff, I8 June I894, William Canniff Papers, Archives of Ontario. I am grateful to Jennifer J. Connor for bringing this correspondence to my attention.

54 Ibid.

55 Berkinshaw to Canniff, 25 June 1894 , Canniff Papers.

56 Berkinshaw to Canniff, 4 August I 894 and Briggs to Canniff, 2 I August I894, Canniff Papers.

57 Berkinshaw to Canniff, 26 October I894, Canniff Papers.

58 Berkinshaw to Canniff, 9 April I 895, Canniff Papers.

59 Berkinshaw to Canniff, 2 October I 894, Canniff Papers.

60 Briggs [Caswell] to Traill, 22 May 1894, Traill Family Papers, MG29 D8I, National Archives of Canada.

6I Draft of letter, Traill to Briggs, 3I August I 894, Traill Family Papers.

62 Briggs [Caswell] to Traill, 5 September 1894 , Traill Family Papers.

63 Ibid.

64 Briggs [Caswell] to Traill, I5 September 1894, Traill Family Papers.

65 Caswell to Traill, 15 January 1895 , Traill Family Papers.

66 James L. Hughes, 'Ministry of Nature in Moral Development,' Methodist Magazine 4I (February I895): $16 \mathrm{I}$.

67 For example, Caswell wrote Traill on 19 December 1894 that he was thinking of 'sending complimentary copies in half-calf binding to Prof. Goldwin Smith, Principal Dawson, Principal Grant and Lady Aberdeen, asking them to give me a condensed opinion of the book on a page of note paper with a view to having a facsimile etching made of the their letters and using them as a four-page circular.' Traill Family Papers.

68 Caswell to Traill, 12 February 1895 , Traill Family Papers.

69 Caswell to Traill, I5 February I895, Traill Family Papers.

70 Royalty statement, 30 March I 895, Traill Family Papers.

7 I Caswell to Traill, 9 April I 895, Traill Family Papers.

72 For a further explanation of this problem see George L. Parker's article, 'The Canadian Copyright Question in the I890s,' Journal of Canadian Studies I I (May 1976): 43-55.

73 Parker, The Beginnings of the Book Trade in Canada, 228.

74 Caswell to Traill, 9 April I 895, Traill Family Papers.

75 See, for example, William Wilfred Campbell, Archibald Lampman, and Duncan Campbell Scott, At the Mermaid Inn Introduced by Barrie Davies (Toronto: University of Toronto Press, 1979/34, 84, 140, 227, and Sara Jeannette Duncan, Selected Journalism, ed. Thomas E. Tausky (Ottawa: Tecumseh Press, 1978), 108.

76 Briggs to Traill, II April I 895, Traill Family Papers.

77 Briggs [Caswell] to Traill, I October 1894, Traill Family Papers.

78 Caswell to Traill, 15 January 1895 , Traill Family Papers. 
79 Caswell to Traill, 9 March 1895 , Traill Family Papers.

80 Caswell to Traill, 12 June 1895 , Traill Family Papers.

8I Caswell to Traill, i7 December I895, Traill Family Papers.

82 Caswell to Traill, I2 October I 895, Traill Family Papers.

83 'Praise from Lady Aberdeen,' Bookseller and Stationer 22 (February I896) : 14.

84 Royalty statement, 3I March I896, Traill Family Papers.

85 Caswell to Traill, I 8 December I 895 and Briggs to Traill, 12 August I896, Traill Family Papers.

86 Briggs to Traill, I2 August I896, Traill Family Papers.

87 The royalty statement of 3 September 1896 showed twenty-six copies of Pearls and Pebbles and ninety-four copies of Cot and Cradle Stories had sold in the previous six months. For the same period the following year, twenty-two copies of Pearl and Pebbles and eighteen copies of Cot and Cradle Stories were sold. Traill Family Papers.

88 Caswell to Traill, I December I 898, Traill Family Papers.

89 Canadian Wild Flowers does not appear on Traill's royalty stubs. Given that the book contained hand-painted illustrations, was an extremely limited edition, and was a costly $\$ 6.00$, it was likely a subscription publication. Caswell's non-involvement in the book's production also substantiates this idea, suggesting that it was handled by the House's subscription book department. For details of Studies in Plant Life's publication, see Briggs Agreement \#25, box 6; and Bookseller and Stationer 2 I (June I905) : 208.

90 'Books and Authors,' Canadian Magazine ıo (January r 898) : 282.

91 Bookseller and Stationer i 4 (January I 898): 6.

92 Henry J. Morgan Correspondence, files I-3, box Io.

93 Form letter from William Briggs, I3 May I9I2, George Parkin Papers, MG 30 D44, National Archives of Canada.

94 'A Page About Books by Canadian Authors,' Bookseller and Stationer 24 (October I908) : 31 .

95 Caswell to Kirby, 23 February 1899, Kirby Papers.

96 Caswell to Kirby, 23 March I 899, Kirby Papers.

97 E.H. Dewart, 'Introductory Essay' in Alexander McLachlan, The Poetical Works of Alexander McLachlan (Toronto: William Briggs, 1900), 13.

98 Bookseller and Stationer I8 (June I902): I 4.

99 Charles Mair to G.T. Denison, I4 October 1901, George Taylor Denison Papers, MG29 E29, National Archives of Canada.

Ioo Mair to Denison, 6 July I90I, Denison Papers.

IOI Mair to Denison, 20 June 1901, Denison Papers.

I02 Mair to Denison, 6 July r9oi, Denison Papers.

I03 Caswell to Denison, 3 I July 1901, Denison Papers.

I04 Ibid.

I05 Ibid.

ro6 Caswell to Denison, 7 August 1901, Denison Papers.

I07 Caswell to Denison, 3 I July 1901, Denison Papers.

I08 Mair to Denison, I5 August 1901, Denison Papers. 
109 Mair to Denison, 16 December 1901, Denison Papers.

I Io Mair to Denison, 2 I October 1901, Denison Papers.

I I Mair to Denison, 24 November I901, Denison Papers.

II 2 Mair to Denison, I4 October 1901, Denison Papers.

II3 Briggs Agreement \#I. Those listed were the Christian Guardian, Canadian Baptist, Canadian Churchman, Canadian Congregationalist, Westminster Magazine, Sunday School Banner, Intermediate Quarterly, Adult Bible Class Monthly, The Leader (Ontario Sunday School Association), Senior Quarterly, Epworth Era, Acta Victoriana, Vox Wesleyana, Lux Columbia, Mclean's Magazine, The Globe, The Mail and Empire, The Toronto Daily Star, Vox Collegii (Ontario Ladies' College, Whitby).

I 4 William Arthur Deacon, Poteen: A Pot-Pourri of Canadian Essays (Ottawa: The Graphic Publishers, 1926), 203.

I 5 W.W. Campbell, 'Canadian Poetry,' (letter to the editor) Globe (Toronto), I 3 April 190I, 23. Campbell edited both The Oxford Book of Canadian Verse (1913) and Poems of Loyalty by British and Canadian Authors (1913).

II 6 Theodore H. Rand, ed. A Treasury of Canadian Verse (Toronto, London: William Briggs, J.M. Dent, 1900), xii.

I 17 Bookseller and Stationer I7 (December I901): 8 and 20 (February 1904): 45 .

I 8 Ethelwyn Wetherald to John W. Garvin, 8 October [1905?], Lorne Pierce Papers, file I, box 33, 200Ib, Queen's University Archives.

I 9 Pauline Johnson, The Moccasin Maker (Toronto: William Briggs, 1913), 6, 9.

I20 John W. Garvin to Lorne Pierce, 8 March 1935, file I, box 33, Pierce Papers.

I2 I Caswell to Garvin, 9 April I907, file I, box 33, Pierce Papers.

122 'A Lack of Appreciation,' Canadian Magazine 29 (May 1907) : 98.

I23 Ibid.

I24 'Publisher's Announcements,' Bookseller and Stationer 2 I (May 1906) : Io.

I25 Burpee to Horning, 6 November 1900, Caswell to Horning I3 July 1903 and Caswell to Horning 17 May 1904, Lewis Emerson Horning Papers, E.J. Pratt Library, University of Toronto.

126 Caswell to Horning, 26 May 1904, Horning Papers.

127 Cooper to Caswell, 27 May 1904, Horning Papers.

I 28 Parker, The Beginnings of the Book Trade in Canada, 237.

I29 Briggs [more than likely written by Caswell] to McClung, I 3 July I905, Nellie McClung Papers, Add. Mss. Io, British Columbia Archives and Records Service. I30 Ibid.

I 3 I Briggs [Caswell] to McClung, 3 I July 1905, McClung Papers.

I32 Briggs [more than likely written by Caswell]to McClung, I2 September 1905, McClung Papers.

133 William Briggs to Hiram Cody, I4 October 1909, Miscellaneous Correspondence, Hiram A. Cody Papers, General Synod, Archives, Anglican Church of Canada

I 34 See Michael A. Peterman, 'Susanna Moodie (1803-1885),' Canadian Writers and their Works Fiction Series. vol. I. ed. Robert Lecker, Jack David, and Ellen Quigley. (Downsview, Ont.: ECW Press, I983), 84-7. 
I35 Ibid.

I 36 Cited in Carl Ballstadt, Editor's Introduction to Susanna Moodie, Roughing It in the Bush (Ottawa: Carleton University Press, 1988), xxxiii.

I 37 Cited in George L. Parker, 'A History of a Canadian Publishing House: A Study of the Relation Between Publishing and the Profession of Writing' (Ph.D. diss., University of Toronto, 1969/, 70.

I 38 See also ibid., 65-75.

I 39 Caswell to McClung, I 2 May 1906, McClung Papers.

I40 Mary Hallett and Marilyn Davis, Firing the Heather (Saskatoon: Fifth House Ltd., 1993|, 232-4.

I4I Hallett and Davis argue that Caswell encouraged McClung to seek unrealistically high royalties and describe his editorial suggestions as 'prim' and 'pious'. (Firing the Heather 232-3) However, the higher royalty he suggested was consistent with those offered bestselling authors while his editorial advice reflected his own knowledge of the market and, quite possibly, a concern for the House's religious affiliation. McClung's assessment of Caswell appears in The Stream Runs Fast: My Own Story (Toronto: Thomas Allen Ltd., 1945), 76.

I 42 Caswell to McClung, 6 March 1908, McClung Papers.

I43 Briggs [Walker] to McClung, 6 April 1908, McClung Papers.

144 Caswell to McClung, I6 May I908, McClung Papers.

I 45 Caswell to McClung, 4 September 1908, McClung Papers.

146 Caswell to McClung, 9 October 1908, McClung Papers.

I 47 'A Page About Books by Canadian Authors,' Bookseller and Stationer $24(22$ February 1908) : 22; and 'Gossip of the Month,' Canadian Bookman I (January 1909) : 2. See also Peter J. Mitham, 'The Publication of Songs of a Sourdough,' Papers/Cahiers 34, no. I (spring 1996): I 3-35.

I48 R.B. Bond, 'I Sold Service to the Public,' Globe Magazine, 28 June 1958, 7.

149 Cited in Parker, A History of a Canadian Publishing House, 99.

I 50 Walker to Pierce, 7 December 1938, Pierce Papers.

I 5 I Bond, 'I Sold Service to the Public,' 8.

I 52 Cost of Selected Works Ledger, box 3.

I 53 J.D. Logan, 'Dr. Logan's Reply,' Canadian Magazine 40 (April I9I3) : 590.

I54 Robert W. Service, Ploughman of the Moon (New York: Dodd, Mead, I945), 350-I.

I55 Deacon to Pratt, 2 I June 1923, William Arthur Deacon Papers, Thomas Fisher Rare Book Library, University of Toronto.

I 56 Robert W. Service, The Pretender (Canadian Edition) (New York: Dodd, Mead, 1914), preliminary page. The Canadian edition is distinguishable from the American edition by this notice. Both carry the imprint of the American publisher.

I 57 Robert W. Service, The Pretender. (American Edition) (New York: Dodd, Mead, I9I4), I45.

I 58 Service, The Pretender (Canadian Edition), I 45.

I 59 John Webster Grant, 'Ryerson Press, The,' in The Oxford Companion to Canadian Literature ed. William Toye (Toronto: Oxford University Press, I983), 722. 
I60 See Wallace, The Ryerson Imprint, 56-62.

I6I Parker, A History of a Canadian Publishing House, 56.

I62 Unwin to Stead, 7 September 1915, Robert J.C. Stead Papers, MG30 D74, National Archives of Canada.

163 Stead to Unwin, 22 September 1915 , Stead Papers. Permission to quote from this letter has been kindly granted by the estate of Robert J.C. Stead.

I64 Parker, $A$ History of a Canadian Publishing House, 52-4.

I65 Ibid., 53.

166 Pierce, The House of Ryerson I 829-1954, 46.

I67 E.J. Moore, 'Our New Hymn Book,' Christian Guardian 88 (3 I October 1917): 14-5.

I68 William Briggs, 'Our New Hymn Book,' Christian Guardian 88 (2 I November 1917): 2.

I69 Ibid..

170 Parker, A History of a Canadian Publishing House, 59-60.

17I Stead to Unwin, 22 September 1915, Unwin to Stead 12 October 19 I 5 and Stead to Unwin, 27 October 1915, Stead Papers.

172 Parker, A History of a Canadian Publishing House, 80-I.

173 See Danielle Hamelin, 'Shaping the Canadian Reading Public: The Macmillan Company of Canada, I906-192I,' A paper given at the Canadian Historical Association Conference, June 1993.

I74 Ibid., I 3.

175 Report of the Book Committee, Journal of Methodist Conference I 9 I 8 (Toronto: William Briggs, I9181, I66-7. 
